Article

\title{
University Students' Social Demand of a Blue Space and the Influence of Life Experiences
}

\author{
Jason P. Julian *, Graham S. Daly and Russell C. Weaver \\ Department of Geography, Texas State University, San Marcos, TX 78666-4684, USA; \\ graham.daly@txstate.edu (G.S.D.); rcweaver@txstate.edu (R.C.W.) \\ * Correspondence: Jason.Julian@txstate.edu; Tel.: +1-512-245-3201
}

Received: 7 July 2018; Accepted: 27 August 2018; Published: 5 September 2018

\begin{abstract}
Blue spaces such as rivers provide many ecosystem services (ES), including freshwater for consumption, habitat, water quality regulation, and multiple cultural amenities. While many studies have quantified the biophysical supply of ES provided by rivers, fewer have explored the social demand for ES due to the considerable effort involved in collecting these data. The San Marcos River (SMR) and the Texas State University (TXST) students that use this blue space represent a dynamic social-ecological system (SES) where nature experiences shape student values of the system. In this study, we survey the TXST student population about their use, value, and perception of the SMR, a highly used river of which headwaters originate on and flow through campus. From our extensive survey of these students, we find that educational and life experiences matter. Overall, we find that student exposure to the SMR in space, time, and experience does have measurable effects on their use, value, and perception of ES. This SES study demonstrates the importance of life experiences, place-based knowledge, and experiential learning in influencing one's well-being and value of natural environments.
\end{abstract}

Keywords: ecosystem services; social demand survey; social-ecological systems; university student perceptions; urban streams

\section{Introduction}

An ongoing challenge for environmental, cultural, and economic sustainability is how to maximize our benefits from blue spaces without degrading them. Blue spaces, originally an urban planning term for surface water, are now studied and managed within the context of how water features affect human well-being [1-3]. However, blue spaces are also impacted by human uses and demands. Thus, blue spaces can be treated as a social-ecological system (SES), where people and water resources are linked through feedbacks with an adaptive capacity [4-6]. A common approach to investigate SES dynamics is the ecosystem services (ES) framework, popularized by the Millennium Ecosystem Assessment [7]. More recently, the Common International Classification of ES (CICES) was created in an attempt to offer a single classification system that allows the multiple typologies of ES descriptions to be aggregated and organized in a structured fashion [8]. The CICES emphasizes "final services" that are more recognizable by the public in ES questionnaires, and thus we adopt their definitions as follows (Table 1). Provisioning services are the natural resources that we directly consume. Regulating services arise from functional ecosystem processes, such as air quality and water quality. Cultural services are the non-material and non-consumptive benefits of ecosystems, including but not limited to: aesthetics, sense-of-place, spirituality, recreation, and education. Many place-based studies have analyzed ES of different blue spaces including lakes [9], rivers [10], bays [11], and oceans [12]. The broader importance of water resource ES has also been well described in the literature $[4,13]$. 
Table 1. Ecosystem services framework for the San Marcos River blue space, adapted from $[7,8]$.

\begin{tabular}{cl}
\hline Ecosystem Service Class & Ecosystem Service Descriptions \\
\hline \multirow{2}{*}{ Provisioning } & Water source for municipal, agricultural, and industrial consumption \\
& Fish as food source \\
\hline \multirow{3}{*}{ Regulating } & Water quality and purification \\
& Habitat for plants and animals \\
& Climate regulation and heat reduction \\
\hline \multirow{3}{*}{ Cultural } & Recreational opportunities \\
& Aesthetic experiences \\
& Cultural heritage relationships \\
& Educational resources \\
& Inspirational qualities \\
& Spiritual significance \\
\hline
\end{tabular}

Ecosystem service measurements, whether they be provisioning, regulating, or cultural, involve the process of assessing and accounting for (and sometimes mapping) the bundle of ES [14]. Accounting for ES inherently considers the supply and demand of the services [15]. Social demands for ES are based upon a range of social contexts $[16,17]$, including the individual and collective use, value, and perception of available benefits [18]. Accordingly, the social demand for ES is largely dependent upon the stakeholder (sensu) [19] using and valuing the services [20]. Representing stakeholder perspectives can be accomplished through multiple methods [21], all of which involve engaging individuals to determine group values [22]. We agree with those near [23] and far [24] that representing diverse stakeholders in watersheds is important when discussing ES management decisions. This study contributes to the growing interest in and application of survey methodology to represent diverse stakeholder groups, with a focus on university students.

University students are characterized as experiencing one of their most formative life stages-emerging adulthood [25]. This period of development is marked by unparalleled opportunities and freedoms for young individuals to explore their environment. With these new-found freedoms, however, new-found stresses and demands come [26-28]. These social demands can be influenced by numerous factors, particularly life experiences and education $[18,29,30]$. The two research questions we address here are: (1) which blue space ES are in greatest demand by university students? and (2) which life experiences influence students' social demand of blue spaces?

While several studies have investigated the benefits and social demand for greenspaces used by university students [31-33], none, to our knowledge, have quantitatively explored the social demand of blue spaces by university students (see Windhorst and Williams [34] for a qualitative study). Here, we use a blue space case study and an SES approach to illustrate (1) how social actors (i.e., students) interact with their environment; (2) how this interaction is connected with social demand; and (3) which factors likely influence this social demand. Our project included investigating stakeholder demand for blue space ES and considered group interactions.

\section{Study Area}

\subsection{San Marcos River}

The blue space examined here is the San Marcos River (SMR) (Figure 1), which drains $130 \mathrm{~km}^{2}$ of the Texas Hill Country that is mostly grasslands and oak/juniper woodlands. The baseflow of the river (a median discharge of $5 \mathrm{~m}^{3} / \mathrm{s}$ ) is derived from groundwater that has filtered through the karst Edwards Aquifer system and emerges at the San Marcos Springs within the impounded Spring Lake. The water exiting the springs is well above drinking water quality standards for cleanliness/clarity and has never run dry in recorded human history [35]. Largely due to the continuous flow of high-quality groundwater, the river system is home to seven unique species that are either endangered or threatened, 
with several being endemic to the river system [36]. After the water leaves Spring Lake, it becomes the SMR and its shorelines are publicly accessible parklands owned by Texas State University and further downstream by the City of San Marcos (Figure 1). These river parks receive approximately 300,000 visitors every year, including residents, students, and tourists from around the world. With the river being so integrated into the built environment, a strong sense of place is present and the numerous interactions provide many opportunities to study cultural ES [35].

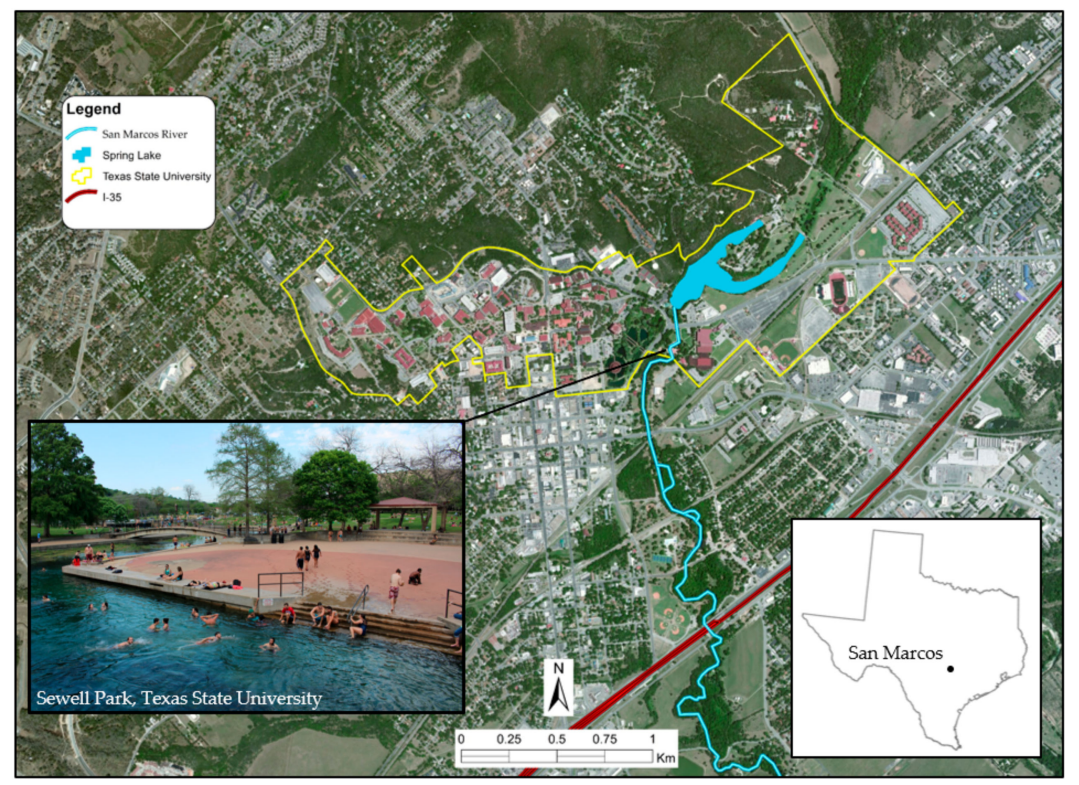

Figure 1. San Marcos River blue space within Texas State University and the City of San Marcos, Texas, USA.

\subsection{City of San Marcos}

The City of San Marcos (>60,000 people in 2015) has recently experienced tremendous growth rates. From 2010 to 2014, the city population increased by more than $31 \%$, making it the fastest growing city in the USA by percentage for three consecutive years. San Marcos is increasingly recognized as one of the more desirable places to live, receiving multiple awards for quality of life and business stability [37]. There are multiple factors accounting for the desirability and growth of the region. Located between Austin and San Antonio, Texas (Figure 1), two of the largest and fastest growing metropolitan areas in the USA, San Marcos provides a more affordable small town living experience with many natural and cultural amenities. San Marcos has one of the highest greenspace ratios per capita for the entire state of Texas with over 2000 acres in the 35 plus parks owned and managed by the city [38]. Located within city limits is the Tanger/Premium Outlets ${ }^{\circledR}$ mega-mall-complex that receives over 10 million visitors a year, grosses over 15 million dollars in annual sales, and accounts for approximately $40 \%$ of the city tax revenue. While this tax base is an extremely important income source and an employer for the city residents, it is Texas State University that is the single largest employer [39].

\subsection{Texas State University}

The main campus of Texas State University, which has a footprint of $2 \mathrm{~km}^{2}$, sits upon a prominent hill that is adjacent to the historical downtown square and the headwaters of the SMR (Figure 1). Beginning in 1903 with 303 students, the university has grown into an aspiring tier one research university with a Division I athletics program, attracting students from across the globe. In 2015, there were approximately 35,000 enrolled students, which made up more than half of the city's population. The growth in population and status of the city and university around a high-quality 
and easily accessible urban river provides an excellent case study to investigate social demand of a blue space within the context of SES framing.

\section{Methods}

\subsection{Survey Instrument}

To begin to measure the demand for ES by university students, we designed a questionnaire that inquired about student use, value, and perceptions of the SMR. We conducted our survey during the final two weeks of the 2015 Spring Semester. Using Qualtrics software (2015 Research Core version, Qualtrics, Provo, UT, USA), we emailed an introductory letter and a hyperlink to the survey questionnaire to all 34,916 enrolled students. Our letter included the IRB exemption (EXP2015Y9517771) and assured respondents of anonymity. For incentive, we offered participants a chance to be randomly drawn to receive $\$ 50$ (ten total awards). We sent two follow-up reminder emails to those who did not fill out or complete the survey.

The questionnaire (Appendix A) began with informed consent and consisted of 49 questions that took an average duration of fifteen minutes to complete. The survey questions were organized into five main data categories: (1) use of the river and its ES; (2) value of the river ES; (3) perception of the river ES; (4) socio-demographics, including student specific information; and (5) life experiences. We collected data on individuals and also designed questions to group students based on socio-demographic and life experience variables.

Life experience refers to life history between early childhood and recent college experiences. We asked about environment in which students were raised to distinguish between rural, urban, and suburban areas. We paired environment with exposure by asking about time spent outside during childhood as regularly, occasionally, rarely, and never. Lastly, we asked about current residence and more recent experiences in San Marcos. Time lived in San Marcos was used as a proxy for temporal exposure, while proximity of residence to the river was a surrogate for spatial exposure. We also added a question on participation in the glass bottom boat tours at Spring Lake to assess educational exposure.

Student influence on social demand was collected by asking questions that characterized and quantified their use of ES. We collected data on where, when, with whom, how often, and for what purposes students visited the river. This information allowed us to characterize student use of the river, which is primarily an exploration of cultural ES, similar to [40].

To understand how university students value and need the ES of the SMR, we employed a line of questioning similar to other ES social demand studies [23,41]. We asked the respondents to rank different ES in terms of importance. In designing these ranking and ordinal response questions, we deliberately asked multiple questions that allowed us to compare student values of different provisioning, regulating, and cultural services.

\subsection{Data Analyses}

Student response data underwent two steps of analysis. First, we examined descriptive statistics and distributions of responses for each question. During this process, we flagged potential outliers and nonsensical responses. The second round of analysis involved comparing the student-ranked responses of use, value, and perception across demographic and life experience variables by running non-parametric Kruskal-Wallis tests, followed by post hoc pairwise Wilcoxon tests where warranted, and identifying statistical significance $(\alpha=0.05)$. Chi-squared tests for independence were used in situations where the two variables under investigation were both categorical. While this line of non-parametric analyses cannot reveal causal links between life experience variables and student responses, it did highlight potential relationships that are being investigated using more sophisticated statistical modeling techniques in the next phases of our analysis. Importantly, our survey design allowed us to treat many of the students' responses as both independent and dependent variables 
during these subsequent phases of our overall research project, so that we could cross-reference responses and ask both 'if' and 'how' questions. For example, use of the river was treated as a dependent variable to investigate 'if' it is meaningfully related to life experiences, while it was also analyzed as an independent variable to understand 'how' life experiences might affect perception and value of ES.

\section{Results and Discussion}

\subsection{Socio-Demographics, Life Experiences, and Use of the Blue Space}

We received 2580 survey responses for a 7.4\% overall response rate from the Texas State University student population of 34,916 . The demographics of our sample compared favorably with the student population in terms of class standing, degree, age, and race/ethnicity (Table 2). One notable difference was the over-representation of females in our sample (+12 percentage points relative to the population), which is not surprising given that existing literature shows females are more likely than males to respond to survey questionnaires [42]. Another notable difference was the greater representation of graduate students in the sample ( +6 percentage points, collectively), which may be due to their greater involvement in the overall college experience [43]. Overall, student respondents were predominantly young (76\% between 18 and 25 years) and female (69\%). Just over half of students identified as White (51\%), with Hispanic being the largest non-White ethnic group (19\%), followed by Black $(4 \%)$. A large majority of respondents (83\%) reported an annual income of $\$ 20,000$ or less, which is characteristic of student populations [44]. Students reported to have parents that had higher education attainment rates than the national average; more than half (56\%) of student respondents' parents had completed a bachelor's degree or higher. The 2015 U.S. Census national average rate of $33 \%$ for college degree attainment suggests that students were coming from households with almost twice the national average of college education attainment.

Student respondents came from a predominantly suburban background and regularly spent time outside during childhood (Table 3). Most students (58\%) were raised in a suburban environment, followed by those raised in rural (25\%) and urban (17\%) environments. When compared to 2010 census data for the state of Texas ( $85 \%$ urban, $15 \%$ rural), our student population sample was more rural than the state average. A large majority of respondents $(81 \%)$ regularly participated in outdoor activities during childhood. Four out of every five students lived in the City of San Marcos, with the other one-fifth commuting to campus from neighboring towns within a 50-mile radius ( $88 \%$ of these within 25 miles). Students were found to live close to the SMR and maintain a relatively short residency time in the City of San Marcos. Nearly all of the San Marcos residential students (90\%) lived within five miles of the river, and half of these (50\%) students lived less than two miles from the river. Nine out of every ten students reported living five years or less in the City of San Marcos.

We found that these socio-demographics and life experiences related significantly with student use of the SMR blue space (Tables A1 and A2). Specifically, at least five meaningful differences were identified in Kruskal-Wallis and chi-squared tests, the overall results of which are presented in Appendix B (Tables A1 and A2). First, residency in San Marcos was quite intuitively linked to higher use than non-residency. The median number of annual visits to the SMR for a San Marcos resident was 15 (mean $=33.21)$, compared to 5 median visits for non-residents $($ mean $=19.13)$. This higher overall use gave way to higher use by residents in all seasons as well.

Second, students of different ages reported significantly different numbers of annual visits and had different preferences for the number of individuals who accompanied them to the river. In general, younger students visited the river much more often than older students. Students under $25($ median $=10$, mean $=30.25)$ and between 25 and 34 years old $($ median $=10$, mean $=29.33)$ reported significantly more trips to the river than students between the ages of 35 and 44 (median $=4$, mean $=26.13$ ), and those at 45 years or older (median $=5$, mean $=21.63$ ). Moreover, as age increases, preference to visit the river alone or with one other person seems to increase. The percentages of 
respondents who indicated this preference were: $24 \%$ for students under 25 years old; $46 \%$ for students between 25 and 34 years old; $44 \%$ for students between 35 and 44 years old; and $71 \%$ for students at 45 years or older. Similar patterns, with respect to both reported annual visits and group size preferences, occurred for student status, with undergraduate students (especially seniors) reporting that they visit the river more frequently and in larger groups than graduate students.

Third, post hoc Wilcoxon pairwise tests revealed that students whose parents had less than a high school diploma visited the river significantly less frequently than students whose parents had any other level of education. The median number of visits for students of non-high-school-graduates was 8 , with a mean of 20.52 visits, whereas for all other groups, the median number of visits ranged from 10 (for four of six remaining groups) to 15 (bachelors degree), with a mean in the range of 26.82 (high school diploma) to 36.21 (doctoral degree).

Table 2. Texas State University student population and sample socio-demographics. Totals may not add to $100 \%$ due to rounding.

\begin{tabular}{|c|c|c|c|}
\hline Socio-Demographics & Categories & Spring 2015 Enrollment & Survey Respondents \\
\hline Students & Total number & 34,916 & $2580(7.4 \%)$ \\
\hline \multirow{6}{*}{ Student level } & Freshman & $13 \%$ & $12 \%$ \\
\hline & Sophomore & $19 \%$ & $16 \%$ \\
\hline & Junior & $23 \%$ & $23 \%$ \\
\hline & Senior/Postbaccalaureate & $33 \%$ & $32 \%$ \\
\hline & Masters/Professional & $10 \%$ & $14 \%$ \\
\hline & $\mathrm{PhD}$ & $1 \%$ & $3 \%$ \\
\hline \multirow{2}{*}{ Gender } & Female & $57 \%$ & $69 \%$ \\
\hline & Male & $43 \%$ & $31 \%$ \\
\hline \multirow{6}{*}{ Age } & $<25$ & $74 \%$ & $76 \%$ \\
\hline & $25-34$ & $15 \%$ & $17 \%$ \\
\hline & $35-44$ & $5 \%$ & $4 \%$ \\
\hline & $45-54$ & $3 \%$ & $2 \%$ \\
\hline & $55-64$ & $1 \%$ & $1 \%$ \\
\hline & $65+$ & $1 \%$ & $0 \%$ \\
\hline \multirow{7}{*}{ Race/Ethnicity } & American Indian & $1 \%$ & $<1 \%$ \\
\hline & Asian/Pacific Islander & $3 \%$ & $3 \%$ \\
\hline & Black & $9 \%$ & $4 \%$ \\
\hline & Hispanic/Latino & $32 \%$ & $19 \%$ \\
\hline & White & $51 \%$ & $51 \%$ \\
\hline & Other & $2 \%$ & $8 \%$ \\
\hline & Multiple & NA & $16 \%$ \\
\hline \multirow{5}{*}{ Personal income } & $<\$ 20,000$ & $34 \%$ & $83 \%$ \\
\hline & $\$ 20,000-\$ 40,000$ & $27 \%$ & $10 \%$ \\
\hline & $\$ 40,000-\$ 60,000$ & $16 \%$ & $4 \%$ \\
\hline & $\$ 60,000-\$ 80,000$ & $9 \%$ & $2 \%$ \\
\hline & $>\$ 80,000$ & $14 \%$ & $1 \%$ \\
\hline \multirow{6}{*}{$\begin{array}{l}\text { Parental education } \\
\text { attainment }\end{array}$} & Some High School or less & $12 \%$ & $6 \%$ \\
\hline & High School Graduate & $88 \%$ & $94 \%$ \\
\hline & Some College & $59 \%$ & $82 \%$ \\
\hline & $\begin{array}{c}\text { Associate/Technical } \\
\text { Degree }\end{array}$ & $42 \%$ & $66 \%$ \\
\hline & Bachelor Degree & $33 \%$ & $56 \%$ \\
\hline & Advanced Degree & $12 \%$ & $30 \%$ \\
\hline
\end{tabular}


Table 3. Texas State University student sample life experiences $(n=2580)$.

\begin{tabular}{|c|c|c|}
\hline Question & Answer & Distribution \\
\hline \multirow{2}{*}{ San Marcos resident } & Yes & $93 \%$ \\
\hline & No & $7 \%$ \\
\hline \multirow{5}{*}{ Years lived in San Marcos } & 52 & Maximum \\
\hline & 4 & 75\% Quartile \\
\hline & 2 & Median \\
\hline & 1 & 25\% Quartile \\
\hline & 0 & Minimum \\
\hline \multirow{5}{*}{$\begin{array}{l}\text { Proximity to San Marcos River } \\
\text { (miles) }\end{array}$} & 20 & Maximum \\
\hline & 3 & 75\% Quartile \\
\hline & 2 & Median \\
\hline & 1 & 25\% Quartile \\
\hline & 0 & Minimum \\
\hline \multirow{3}{*}{ Environment raised in } & Rural & $17 \%$ \\
\hline & Suburban & $58 \%$ \\
\hline & Urban & $25 \%$ \\
\hline \multirow{4}{*}{ Time outside during youth } & Regularly & $81 \%$ \\
\hline & Occasionally & $16 \%$ \\
\hline & Rarely & $2 \%$ \\
\hline & Never & $1 \%$ \\
\hline \multirow{2}{*}{ Glass bottom boat tour } & Yes & $63 \%$ \\
\hline & No & $37 \%$ \\
\hline
\end{tabular}

Fourth, the environment in which a student was raised was associated with differential use patterns. Students who reported coming from urban environments claimed to visit the river significantly less frequently (median number of visits $=10$, mean $=25.54$ ) than students who claimed either suburban (median $=12$, mean $=29.63$ ) or rural $($ median $=12$, mean $=32.87$ ) roots. Time spent outside as a child was also linked to differences in both the number of visits that students made to the river and the seasons in which they visited. Students who regularly spent time outdoors as children visited the river in higher frequencies (median $=12$, mean $=32.41$ ) than those who spent time outdoors occasionally ( median $=7$, mean $=18.37$ ) or rarely or never $($ median $=5.5$, mean $=13.24)$.

Lastly, we found that almost two-thirds of the students (63\%) had taken a "glass bottom boat" educational tour at Spring Lake. Participation in the glass bottom boat tour was tied to greater use of the SMR. Specifically, the median number of visits for tour participants was 12 (mean = 32.39), compared to a median of 10 visits for non-participants (mean $=24.69)$.

\subsection{Student Use and Awareness of Ecosystem Services}

When investigating social demand for ES, it is important to first determine the awareness of services in the population generating the demand $[18,23]$. Student responses indicated high usage (Table 4) and an overall awareness of the SMR and its ES (Table 5). Most students (93\%) had visited the SMR at least once prior to taking the survey, and $12 \%$ were regular users who reported visiting the river at least once a week. Students were more likely to visit the river in larger groups and did so quite often during the most popular seasons and time of day. While this high usage is not surprising given that the river flows through campus, results supported the prominence of the river in campus life and confirmed that Texas State University is a blue space with regular interactions between students and their aquatic environment.

The students' close proximity and frequent visits to the river likely increase their familiarity of aquatic ES [23,32]. The formative study by Nisbet et al. [45] highlights an important correlation between increased experiences in natural settings and an individual's perception of 'nature relatedness.' It is through the process of interaction and experience that students at Texas State University likely mature 
their 'nature relatedness' and their value and perception of the SMR. Two frequently cited ES of college campuses associated with well-being utilized by students are relaxation and stress relief $[31,32,46]$; we observed similar results. Indeed, nine out of every ten students agreed that the river provided benefits to human well-being as well as fish and wildlife (Table 5). This statistic supported the idea that students had positive relationships with their local blue space, with a particular appreciation for the regulating and cultural ES.

Recall that more than half of the surveyed students (63\%) had participated in a glass bottom boat tour of Spring Lake. Although the boat tours do not include ES terminology in their educational experience, they do discuss environmental benefits indirectly, which likely contribute further to student awareness of river ES. Hipp et al. [33] surveyed multiple universities and found results that support the use and benefits of campus green spaces. Not only did campus green space contribute to student well-being, but campuses with greater green space resources had students who reported higher rates of well-being. Given the acute awareness of the ES benefits of the SMR by university students, we suggest that the presence of this blue space on campus contributes substantially to student quality of life and that students at Texas State University may have higher rates of well-being, compared to campuses without a blue space.

Table 4. Texas State University student sample use of San Marcos River cultural ecosystem services $(n=2580)$. Totals may not add to $100 \%$ due to rounding. ${ }^{*}$ denotes top five responses, not total responses.

\begin{tabular}{|c|c|c|}
\hline Question & Answer & Distribution \\
\hline \multirow{2}{*}{ Had visited the San Marcos River } & Yes & $93 \%$ \\
\hline & No & $7 \%$ \\
\hline \multirow{5}{*}{ Visits per year } & Maximum & 365 \\
\hline & 75\% Quartile & 30 \\
\hline & Median & 10 \\
\hline & 25\% Quartile & 5 \\
\hline & Minimum & 0 \\
\hline \multirow{5}{*}{ Seasons visited (top 5) * } & Spring, Summer, \& Fall & $29 \%$ \\
\hline & Spring, Summer & $20 \%$ \\
\hline & Winter, Spring, Summer, \& Fall & $16 \%$ \\
\hline & Summer Only & $12 \%$ \\
\hline & Spring Only & $4 \%$ \\
\hline \multirow{5}{*}{ Times of day visited (top 5) * } & Afternoon & $44 \%$ \\
\hline & Morning \& Afternoon & $18 \%$ \\
\hline & Afternoon, \& Night & $13 \%$ \\
\hline & Morning, Afternoon, \& Night & $11 \%$ \\
\hline & Morning & $2 \%$ \\
\hline \multirow{4}{*}{ Group size } & Alone & $7 \%$ \\
\hline & 2 People & $22 \%$ \\
\hline & 3-4 People & $51 \%$ \\
\hline & 5 or More & $19 \%$ \\
\hline
\end{tabular}


Table 5. Texas State University student sample perception and preference of the San Marcos River. Totals may not add to $100 \%$ due to rounding.

\begin{tabular}{|c|c|c|}
\hline Question & Answer & Distribution \\
\hline \multirow{5}{*}{$\begin{array}{l}\text { San Marcos River benefits fish and } \\
\text { wildlife }\end{array}$} & Strongly Agree & $62 \%$ \\
\hline & Agree & $28 \%$ \\
\hline & Neither Agree or Disagree & $9 \%$ \\
\hline & Disagree & $1 \%$ \\
\hline & Strongly Disagree & $0 \%$ \\
\hline \multirow{5}{*}{$\begin{array}{c}\text { San Marcos River benefits human } \\
\text { well-being }\end{array}$} & Strongly Agree & $63 \%$ \\
\hline & Agree & $32 \%$ \\
\hline & Neither Agree or Disagree & $4 \%$ \\
\hline & Disagree & $1 \%$ \\
\hline & Strongly Disagree & $0 \%$ \\
\hline \multirow{5}{*}{$\begin{array}{l}\text { San Marcos River is sensitive to } \\
\text { rapid urban growth }\end{array}$} & Strongly Agree & $55 \%$ \\
\hline & Agree & $31 \%$ \\
\hline & Neither Agree nor Disagree & $13 \%$ \\
\hline & Disagree & $1 \%$ \\
\hline & Strongly Disagree & $0 \%$ \\
\hline \multirow{5}{*}{$\begin{array}{l}\text { San Marcos River is well managed } \\
\text { \& well protected }\end{array}$} & Strongly Agree & $20 \%$ \\
\hline & Agree & $47 \%$ \\
\hline & Neither Agree nor Disagree & $26 \%$ \\
\hline & Disagree & $7 \%$ \\
\hline & Strongly Disagree & $1 \%$ \\
\hline \multirow{3}{*}{$\begin{array}{l}\text { San Marcos River contains } \\
\text { endangered species }\end{array}$} & Yes & $80 \%$ \\
\hline & Not Aware & $18 \%$ \\
\hline & No & $2 \%$ \\
\hline \multirow{5}{*}{ How clean is the San Marcos River } & Very Clean & $21 \%$ \\
\hline & Mostly Clean & $59 \%$ \\
\hline & Not Aware & $12 \%$ \\
\hline & Slightly Dirty & $7 \%$ \\
\hline & Extremely Dirty & $1 \%$ \\
\hline \multirow{6}{*}{$\begin{array}{c}\text { How river water clarity } \\
\text { degradation affects personal } \\
\text { enjoyment of use }\end{array}$} & Does Not Affect My Enjoyment & $2 \%$ \\
\hline & Continue to Enjoy Use & $5 \%$ \\
\hline & Still Enjoy, But Less & $23 \%$ \\
\hline & Greatly Reduce Enjoyment & $44 \%$ \\
\hline & Would Avoid River & $22 \%$ \\
\hline & Do Not Currently Use & $5 \%$ \\
\hline \multirow{4}{*}{$\begin{array}{l}\text { Role of San Marcos River in } \\
\text { attending Texas State University }\end{array}$} & Primary Reason & $3 \%$ \\
\hline & Major Reason & $22 \%$ \\
\hline & Minor Reason & $40 \%$ \\
\hline & Not a Reason & $35 \%$ \\
\hline
\end{tabular}

The vast majority of students (95\%) agreed that the SMR provides benefits to human well-being (Table 5). Moreover, nine out of every ten students believed the river provides benefits to fish and wildlife. These positions were reinforced by the fact that practically the same number of students acknowledged that a reduction in water quality would result in reduced ability to use the river. Specifically, $66 \%$ of the students said reduced water clarity would greatly reduce their ability to enjoy the river, and another $22 \%$ would avoid the river completely if it became dirty and cloudy.

\subsection{Students' Preferences and Social Demand for Ecosystem Services}

While students had a similar general awareness of ES, their preferences for particular services varied widely (Table 6; Figure 2). Regulating service benefits was consistently ranked higher than cultural and provisioning benefits, meaning that the students (collectively) placed higher values on 
the aquatic habitat and water quality of the SMR. This finding accords with previous studies on social demand of ES [40,47,48]; however, our finding of cultural services ranking higher than provisioning services does not match many of these previous studies. This anomaly can be explained by the fact that university students tend to have greater demand for outdoor recreation, education, the arts, and cultural activities [49]. Our study supports previous work highlighting the importance of cultural ES to university students but also suggests that university students are aware of the ES benefit delivery mechanisms of the river. Using the three general categories of value from previous literature (the most recent one is the work done by Gómez-Baggethun et al. [50]), these collective results suggest that students see ecological values as most important, followed by sociocultural values, and lastly economic values.

Table 6. Texas State University student sample ranking of San Marcos River ecosystem services benefits.

\begin{tabular}{|c|c|c|c|}
\hline $\begin{array}{l}\text { Ecosystem Service } \\
\text { Benefits Bundle }\end{array}$ & Specific Ecosystem Service Benefit & Ranked Mean & Ranked Median \\
\hline \multirow{6}{*}{$\begin{array}{l}\text { General ecosystem } \\
\text { service benefits }\end{array}$} & Regulating: habitat for plants and animals & 4.70 & 5 \\
\hline & $\begin{array}{l}\text { Regulating: clean reliable water from } \\
\text { aquifer system }\end{array}$ & 4.22 & 4 \\
\hline & $\begin{array}{l}\text { Cultural: relaxation, scenery, local culture, } \\
\text { sense of place }\end{array}$ & 4.21 & 4 \\
\hline & $\begin{array}{l}\text { Cultural: recreational fishing, swimming, } \\
\text { tubing, boating }\end{array}$ & 3.60 & 4 \\
\hline & $\begin{array}{l}\text { Provisioning: source of municipal, } \\
\text { industrial, agricultural water }\end{array}$ & 2.90 & 3 \\
\hline & $\begin{array}{l}\text { Provisioning: source of fish for your } \\
\text { meals }\end{array}$ & 1.32 & 1 \\
\hline \multirow{6}{*}{$\begin{array}{l}\text { Cultural ecosystem } \\
\text { service benefits }\end{array}$} & $\begin{array}{l}\text { Recreation: tubing, fishing, boating, } \\
\text { swimming, physical health }\end{array}$ & 4.30 & 5 \\
\hline & $\begin{array}{l}\text { Aesthetics: relaxation, scenery, } \\
\text { sentimental value }\end{array}$ & 4.28 & 5 \\
\hline & $\begin{array}{l}\text { Education: experience, learn about, and } \\
\text { appreciate nature }\end{array}$ & 3.79 & 4 \\
\hline & $\begin{array}{l}\text { Cultural heritage: local pride, sense of } \\
\text { place, San Marcos symbol }\end{array}$ & 3.73 & 4 \\
\hline & $\begin{array}{l}\text { Inspiration: artistic, cultural, } \\
\text { work-related activity }\end{array}$ & 2.72 & 2 \\
\hline & $\begin{array}{l}\text { Spirituality: sacred, religious, mental } \\
\text { health activity }\end{array}$ & 2.19 & 2 \\
\hline \multirow{3}{*}{$\begin{array}{l}\text { Water ecosystem service } \\
\text { benefits }\end{array}$} & $\begin{array}{l}\text { Regulating: water quantity and quality, } \\
\text { plant and animal habitat }\end{array}$ & 2.39 & 3 \\
\hline & $\begin{array}{l}\text { Provisioning: municipal, industrial, and } \\
\text { agricultural supply }\end{array}$ & 2.23 & 2 \\
\hline & $\begin{array}{l}\text { Cultural: recreation, aesthetics, } \\
\text { inspiration, spirituality }\end{array}$ & 1.38 & 1 \\
\hline \multirow{3}{*}{$\begin{array}{l}\text { Fish ecosystem service } \\
\text { benefits }\end{array}$} & $\begin{array}{l}\text { Regulating: important part of the } \\
\text { ecosystem and food web }\end{array}$ & 2.79 & 3 \\
\hline & $\begin{array}{l}\text { Cultural: recreational fishing, aesthetics, } \\
\text { environmental education }\end{array}$ & 1.74 & 2 \\
\hline & $\begin{array}{l}\text { Provisioning: nutritional sources of } \\
\text { protein for humans }\end{array}$ & 1.48 & 1 \\
\hline
\end{tabular}




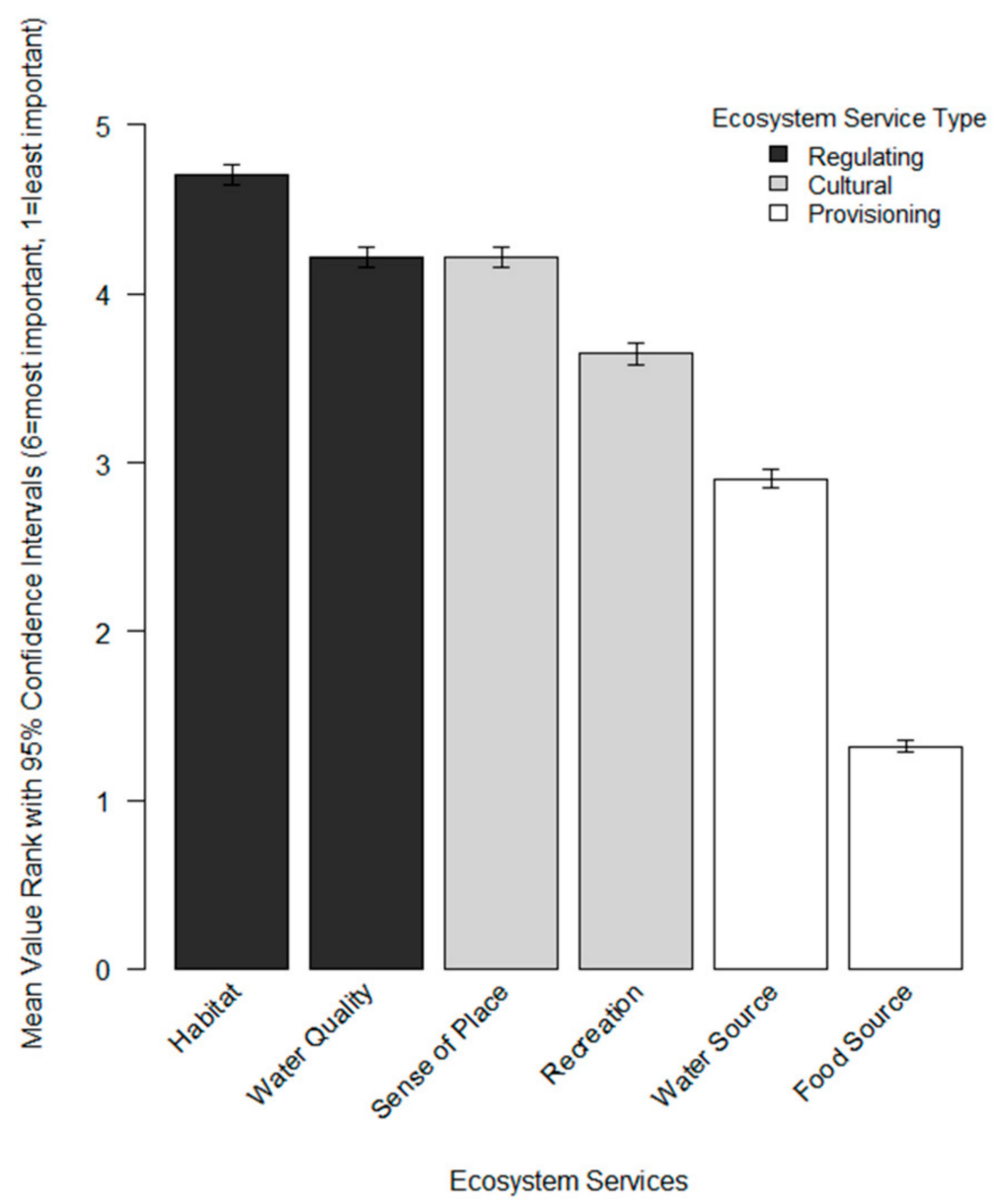

Figure 2. Student valuation of ecosystem services of the San Marcos River, Texas, USA. Error bars represent 95 percent confidence intervals.

To better understand cultural ecosystem services (CES) values of the SMR, we asked students to rank its six main CES. Recreation and aesthetics ranked highest, indicating students (collectively) value most their use of the river associated with their free time and the resulting contributions to their quality of life. Education and cultural heritage were ranked in the middle while inspiration and spirituality were ranked least important (Table 6). As seen in other studies [51], spiritual and inspirational benefits are often less studied and ranked lower than recreational and aesthetic benefits. From the individual perspective, 124 students ranked spirituality first and 79 students ranked inspiration first. While these are small percentages of the collective student body $(5 \%$ and $3 \%$, respectively), their values within the SES should not be marginalized. Indeed, it is quite possible that students benefit spiritually from and/or are inspired by their visual or recreational interactions with blue spaces. In other words, it may not be that students in our sample do not value inspirational and spiritual CES highly; rather, it may be the case that discretely ranked CES categories do not allow students to fully express their more complex CES valuations.

Recent research continues to express concern that CES plays a pivotal role in furthering the agenda of environmental sustainability [52], yet, it has been the most neglected aspect in the ES framework research [53,54]. We agree and suggest our findings of CES values based on university students' opinions may offer insight into their collective and individual socio-cultural values as a stakeholder group. More specifically, we suggest it is the impact of life experiences mediated through CES benefits that continually shape and evolve value and perception of ES held by the individual student. 


\subsection{Connections between Life Experiences and Social Demand of Ecosystem Services}

The commonly accepted definition of a social-ecological system (SES) by Glaser et al. [55] is a fitting starting point for discussing the influence of life experiences on social demand for ES. The SMR serves as the biophysical unit, with Texas State University students as associated social actors. The spatial boundaries consist mainly of the upper portion of the river ecosystem located on campus while the problem context is student social demand. We investigated social demand by asking students about their life experiences, use of the blue space, and preferences for ES. Examining this social demand from an SES framing helps to highlight the connections between life experiences and social demand of ES. We also posed the scenario of reduced water clarity and asked relevant questions to assess how student demand and behavior respond to changes in the SES. An important benefit to employing SES framing in social demand studies is that it allows for both individual and collective group response to be represented in a way that acknowledges their interdependencies [56]. Below, we discuss the main results from our study.

\subsubsection{Current Environment}

We found that not all students used, valued, and perceived the ES of the SMR the same. Individual relationships with ES have been shown to vary with socio-cultural factors [18], particularly the environment in which the social actors live and make use of ES [16,23]. Given that our student sample represented a range of socio-demographics (Tables 2-4), we looked for specific examples of significant associations with student demand (Appendix B). Within the context of student experiences with the SMR, we considered the findings of Baur et al. [57] that exposure to nature experiences can contribute to personal well-being, increase environmental awareness, and promote more environmentally responsible behavior. Indeed, some of the strongest relationships we found related to proximity to and visitation of the river.

Students, who visited the SMR or its neighboring parks during the past year, had significantly more positive or favorable responses to our questions regarding the SMR's benefits, management, and cleanliness (Table 7; test statistics are available in Table A3). Students who visited the SMR put a higher value on recreation and ES related to sense-of-place relative to non-visitors (Figure 3; Table A4). Non-visitors valued provisioning ES (water and food source) and habitat at significantly higher levels relative to visitors. Visitors and non-visitors also diverged significantly on their cultural ES rankings (Table A5). Figure 4 displays the students' mean ranks of the six cultural ES that were included in our questionnaire; the median ranks followed an identical pattern. Those students, who visited the river or its nearby parks in the past year, tended to rank recreation highest (significantly more than non-visitors); whereas almost all non-visitors ranked the river's aesthetic qualities as its most important service. Non-visitors also placed a significantly higher value on the river's educational services (median $=4$, mean $=4.19$ ) relative to visitors (median $=4$, mean $=3.75$ ). Visiting the river was linked to stronger agreement that the SMR is sensitive to rapid urban growth (Table 7; test statistics are available in Table A3), with visitors mostly 'strongly agreeing' that the SMR is sensitive to growth (median $=5$, mean $=4.43$ ) with non-visitors primarily only 'agreeing' with this statement (median $=4$, mean $=2.89$ ). All the differences of these questions described here between visitors and non-visitors were statistically significant at a $99 \%$ level of confidence or better (Tables A3 and A4).

There was further evidence to suggest that nature experiences on the river affect student values and perceptions of river ES. First was the college experience itself, where being exposed to and learning about the on-campus blue space also influenced social demand. For example, post hoc Wilcoxon pairwise tests on selected statistically significant findings from Tables A4 and A6 revealed that the following differences were significant at a $95 \%$ level of confidence or better. First, freshmen placed a lower value (median $=4$ ) on the river's habitat functions relative to all the other student groups (consistent median of 5). Second, residency was associated with significant differences in students' CES rankings. San Marcos student residents valued the river's recreational (median $=4$, mean $=3.71$ ) and 
sense-of-place-related $($ median $=4$, mean $=4.24)$ ES higher than non-residents (recreation: median $=3$, mean $=3.39$; sense-of-place: median $=4$, mean $=4.09$ ).

Table 7. Statistically significant differences in sampled Texas State University student perceptions of the San Marcos River blue space, by selected life experiences (all differences are significant at a 99.9\% level of confidence).

\begin{tabular}{|c|c|c|c|c|c|c|c|c|c|c|}
\hline \multirow[b]{2}{*}{ Visitor status } & \multicolumn{2}{|c|}{$\begin{array}{l}\text { Benefits Fish } \\
\text { and Wildlife }\end{array}$} & \multicolumn{2}{|c|}{$\begin{array}{l}\text { Benefits } \\
\text { Humans }\end{array}$} & \multicolumn{2}{|c|}{ Well-Managed } & \multicolumn{2}{|c|}{ Clean } & \multicolumn{2}{|c|}{$\begin{array}{l}\text { Sensitive to } \\
\text { Urban Growth }\end{array}$} \\
\hline & Med & Mean & Med & Mean & Med & Mean & Med & Mean & Med & Mean \\
\hline Visitor & 5 & 4.56 & 5 & 4.62 & 4 & 3.84 & 4 & 3.99 & 5 & 4.43 \\
\hline Non-visitor & 4 & 4.15 & 4 & 4.12 & 3 & 3.46 & 3 & 3.31 & 4 & 3.89 \\
\hline \multicolumn{11}{|l|}{ Time spent outside } \\
\hline Regular & 5 & 4.56 & 5 & 4.62 & 4 & 3.84 & 4 & 3.97 & 5 & 4.42 \\
\hline Occasional & 5 & 4.44 & 5 & 4.48 & 4 & 3.68 & 4 & 3.87 & 4 & 4.31 \\
\hline Rare or never & 4 & 4.22 & 4 & 4.24 & 3 & 3.48 & 4 & 3.54 & 4 & 4.00 \\
\hline \multicolumn{11}{|l|}{$\begin{array}{c}\text { Glass bottom boat } \\
\text { participation }\end{array}$} \\
\hline Participant & 5 & 4.62 & 5 & 4.64 & 4 & 3.88 & 4 & 4.04 & 5 & 4.46 \\
\hline Non-participant & 5 & 4.39 & 5 & 4.50 & 4 & 3.68 & 4 & 3.77 & 4 & 4.28 \\
\hline
\end{tabular}

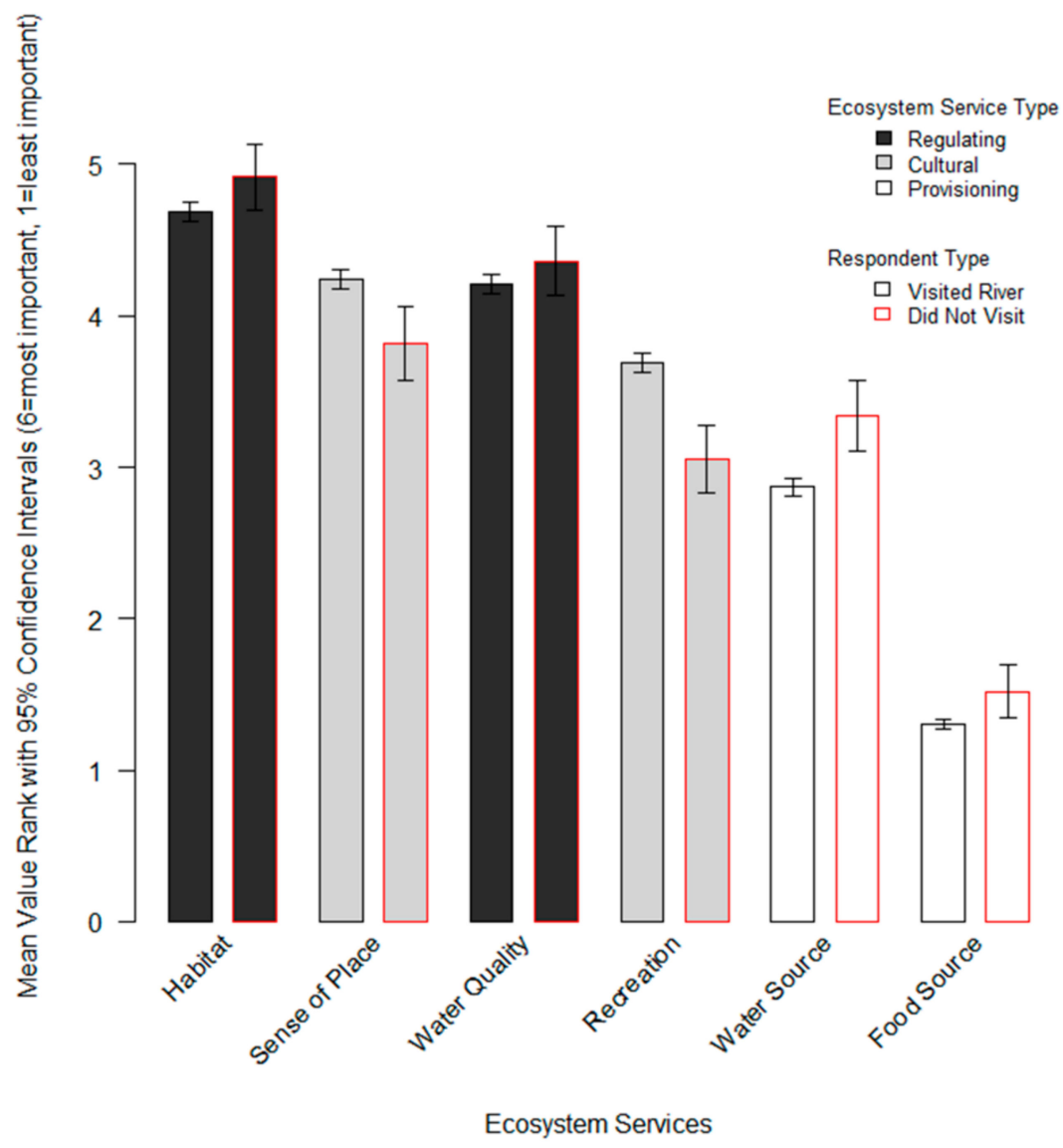

Figure 3. Student valuation of ecosystem services of the San Marcos River (Texas, USA) by visitation. 


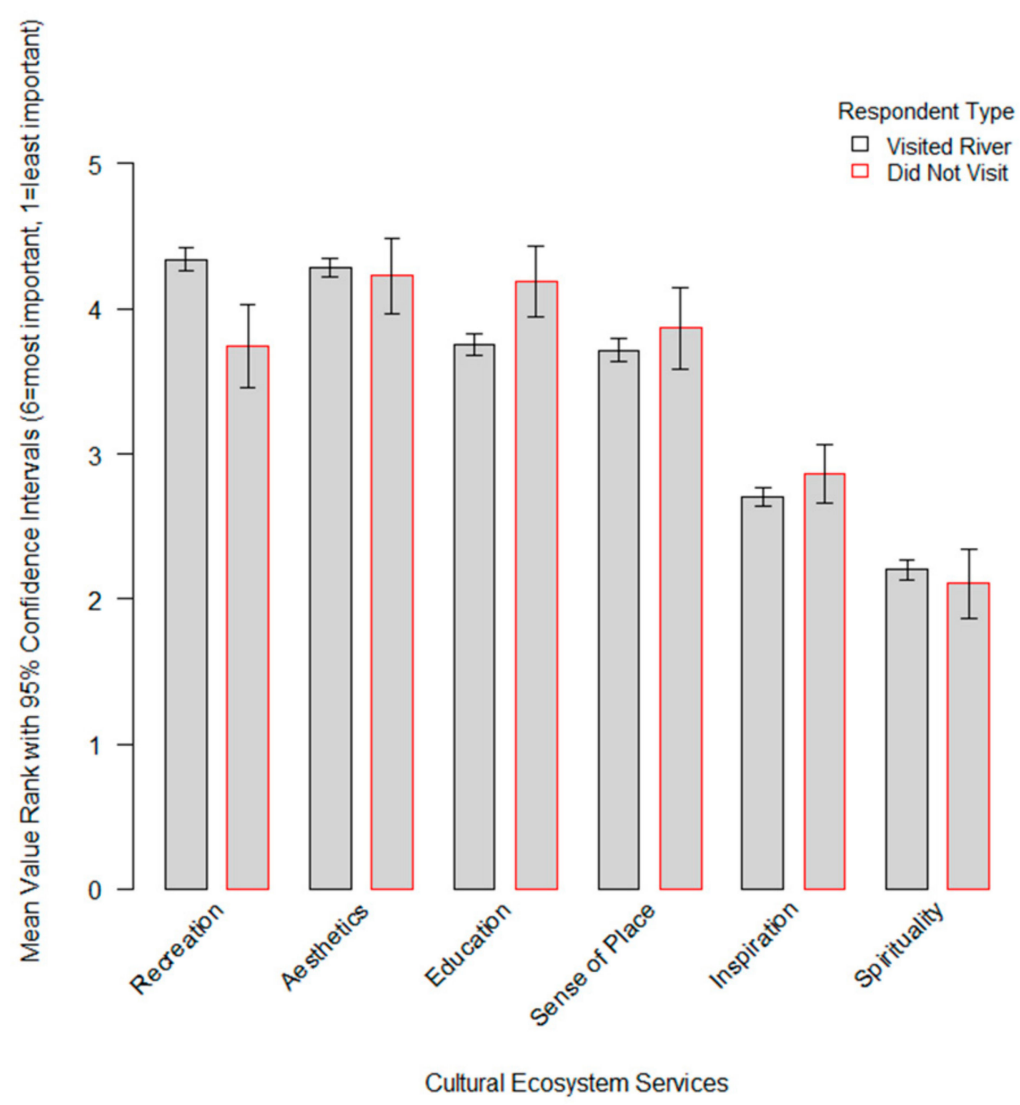

Figure 4. Student valuation of cultural ecosystem services of the San Marcos River (Texas, USA) by visitation.

Altogether, these results on students' current environment/experiences and current use of the river support the following inferences. First, with increased usage of the blue space, students likely become more aware and concerned for their immediate environment. Second, as students mature so do their understanding of their role in the SES; their relationship to place grows and they develop the relational values championed by Chan et al. [52]. After synthesizing forty years of place attachment study findings, Lewicka [58] concedes the following: early phenomenologists were accurate in suggesting that "sense of place is a natural condition of human existence (dwelling = being)". Similarly, we found that the SMR is the site of student-directed place-making and this place-making in turn is directly linked to their awareness and concern for this SES. Adding to recent relevant studies [59-61], we propose that the experiences students have on the river also provide the social environment necessary for students to act out and adopt their developing and relational environmental identity. Through repeated use of the ES of the SMR, the university students (i.e., social actors) are entangled in a positive feedback loop where their use dynamically impacts their perceptions, values, and further use of the river. An alternative interpretation is that students' predisposition to the environment affects their behavior and use of the river. We explore this possibility below.

\subsubsection{Childhood Environment}

Our survey instrument contained many questions on students' childhood experiences and parent socioeconomic status, under the assumption that current behaviors and attitudes are shaped by previous life experiences. While socioeconomic status may not necessarily be a determining factor in how people value nature, it may influence peoples' uses and preferences [30]. Working with a student population, we expected that most individuals would report low income levels not necessarily reflective of student background. Thus, we included parental education level as a secondary indicator of socioeconomic status, which we found to be weakly related to student rankings of ES. 
In particular, post hoc Wilcoxon tests on the two significant associations between parental education and ES rankings (Table A6) yielded the following differences at a 95\% confidence level or better: students from the highest educational attainment households (PhD, MD, or JD) ranked the regulating service of habitat highest (median $=6$, mean $=5.04$; compared to median $=5$ for all the other groups and means falling between 4.62 (Some High School) and 4.77 (High School)); and students from lower educational attainment households ranked the provisioning service of household food source slightly higher than other students (median = 1 for all groups; means range from 1.25 (PhD, MD, JD) to 1.42 (Some High School)). More interestingly, post hoc tests on the significant associations between parental education and CES rankings (Table A7) revealed that students from the highest educational attainment households ranked educational CES lowest, while the students from the lowest educational households ranked educational CES the highest (Table A7). This result potentially indicated that some services may be taken for granted. We also found that as parental education level increased, student perception of the river's sensitivity to rapid urban growth increased (Table A8). These results suggested that students from higher socio-economic backgrounds could have a greater awareness and appreciation for the diversity of ES benefits, not just the provisioning services and economic benefits.

Exposure to outdoor environments during childhood has been shown to be a significant life experience [29,62]. We were curious if childhood outdoor experiences (in terms of time spent outside during youth and environment raised) might influence university student use, value, and perception of the SMR. Both life experiences had significant effects on student responses (Tables A2, A4 and A5). The type of environment in which students were raised-rural, suburban, or urban-was linked to a handful of significant differences in how they ranked the importance of the river, including the provisioning service of water source (Urban ranked higher vs. Rural) and the cultural service of inspiration (Urban ranked higher vs. Rural). Students from urban environments also ranked the cultural service benefits of aesthetics higher than those from suburban environments, suggesting either an increased demand for something they experienced less during childhood or a preference for visual qualities over functional qualities. While use, value, and perception of the SMR did not differ as markedly along students' home environments (rural, suburban, urban) as we anticipated (Tables A2-A5), time spent outside as a youth was strongly associated with these variables.

Students who regularly spent time enjoying outdoor activities during childhood and adolescence visited the SMR blue space significantly more than other students (test statistic in Table A2). More precisely, the median numbers of reported annual visits to the SMR were: 5.5 for students who Rarely or Never spent time outside as a youth (mean $=13.24) ; 7$ for students who Occasionally spent time outside (mean $=18.37)$; and 12 for students who Regularly spent time outside (mean $=32.41$ ). Post hoc Wilcoxon tests showed no difference between the former two groups, while the latter group differed significantly from the others. Students who Regularly spent time outside also had more positive perceptions of the river's benefits relative to their counterparts (Table A3). The median student who was Regularly outside as a child strongly agreed that the SMR benefits fish and wildlife ( median $=5$, mean $=4.56$; compare to: Rare or Never median $=4$, mean $=4.22$; Occasionally median $=5$, mean $=4.44$ ) and humans (median $=5$, mean $=4.62$; compare to: Rare or Never median $=4$, mean $=4.24$; Occasionally median $=5$, mean $=4.48$ ). Similar patterns hold for views on management and cleanliness of the river (Table 7).

Time spent outside as a youth was also associated with greater awareness of the SMR's sensitivity to rapid urban growth (Tables 7 and A3). Post hoc Wilcoxon tests revealed that all pairwise comparisons for the five perception questions were significant at a $95 \%$ level of confidence or better. Time spent outside as a youth was also associated with dissimilar rankings of the ES of habitat, sense-of-place, and inspiration (Tables A4 and A5). Students who Regularly spent time outdoors placed significantly higher rankings on habitat and sense-of-place, likely due to increased familiarity with these concepts. Conversely, students who Rarely or Never spent time outside placed a significantly higher value on the SMR's inspiration CES (median $=3$, mean $=3.16$ ) compared to Occasional (median $=2$, mean $=2.76$ ) and Regular $($ median $=2$, mean $=2.69$ ) outdoor goers. 
Maybe, as Nichols [3] suggests, the novelty of having and using a blue space is a greater source of inspiration.

Overall, it seems that patterns of childhood experiences have carried over into young adulthood, where students who grew up in less urban environments and spent more time outside as a child spend more time at the river and depend on this blue space for their well-being. These results support previous findings by Thompson et al. [63] who showed childhood rates of visitation to natural green spaces were found to be strong predictors of adult visitation patterns. Thus, it may be possible to predict student use, value, perception, and overall demand of ES (at least collectively), based upon their previous life experiences.

\subsubsection{Experiential Education}

We did not find any notable effects of a student's degree program on their awareness or value of ES; however, there was one educational experience that did have a significant effect: glass-bottom boat tours. Texas State University has a partnership with the Meadows Center for Water and the Environment, which is located on Spring Lake (also the headwaters of the SMR). This partnership provides a nationally recognized center for education, research, and community involvement that uses Spring Lake as a natural laboratory and classroom. Glass-bottom boat tours are offered daily year-round and allow patrons to see down into Spring Lake through the crystal-clear waters as their tour guide relays the historical significance, biophysical diversity, and environmental history of the area.

Students who participated in the glass-bottom boat tour ranked the benefits of the river significantly higher than non-participants (Table A3). Specifically, the regulating services of the aquifer, fish, and water quality, as well as cultural services of aesthetics, education, and sense of place were ranked significantly higher than non-participants. Conversely, non-participants ranked the cultural service of recreation the highest. These results of the glass-bottom boat tour effect on student perception were similar to the effect of increased use of the SMR. As with visitation, all of the differences between boat tour participants and non-participants were highly significant at a $99.9 \%$ level of confidence or better. Boat tour participants were also more likely to strongly agree that the river provided benefits to fish and wildlife, human well-being, reported cleanliness, and is sensitive to rapid urban growth. Reflexively, participation in the glass-bottom boat tour was also tied to greater use of the SMR with participants having higher median annual visits and proportional visits across the different seasons, save the busiest season of Summer (Table A2). We note this positive feedback loop associated with use (Figures 3 and 4 ) and glass-bottom boat tour participation is significant and related to other feedback loops we discovered, with actual contact experiences of the river being the common thread that tied them together.

\section{Conclusions}

Place-based knowledge, life experiences, and experiential learning are the influences on social demand of ES that we discovered in this SES study. With our survey of the student population of Texas State University, we were able to gain insight into how university students, as stakeholders and social actors, use, value, and perceive the ES of the SMR. Our findings showed that use, value, and perception of blue spaces are influenced by multiple factors, and that while university students belong to the same stakeholder group, there are important differences among students that shape their social demand for ES. The insights provided from our study can inform approaches to managing on-campus SES more sustainably. Most notable among our findings were the significant associations that life experiences have with student use, value, and perception of ES. The positive feedback loops, whereby use of the river influences perceptions, value, and further use, suggest that direct experiences might play critical roles in shaping social actors' behaviors in SES. The observations that participants in a glass-bottom boat tour/educational experience are, relative to non-participants, (1) significantly more likely to visit the blue space that they learn about during the tour; 
and (2) significantly more aware of the blue space's benefits to humans and wildlife, and of its sensitivity to growth, support recent calls for urban planners and designers to build communities where people have regular opportunities to learn from and about local ecology [64]. When such opportunities are encoded into urban landscapes, the social actors that take advantage of them often become more aware of their roles in ecological systems, and as such, can adjust their behaviors to become better stewards of their environments [64].

In addition to these findings, our study echoes Cortese's [65] implication that investigating social demand using an SES framework moves university campuses towards maximizing their full potential as centers of cultural change and environmental sustainability. The specific situation of San Marcos, Texas is shared by college towns across the world that experience growth and find themselves in prominent town-gown relationships. University students often make up significant portions of the town population and represent an influential stakeholder group that should not be ignored. We suggest that conducting ES-based studies of student use, value, and perception of green and blue spaces can generate valuable data and at the same time enhance town-gown relationships. Oftentimes, the local city government and university leadership work separately, and studies such as ours can serve as common ground information sharing as these communities plan and grow together.

There is also an important consideration that university students, as a stakeholder group, represent the future generation of influential members of society. Better understanding of how students use, value, and perceive ES provides insight into where we are as a society in regard to human-environment interactions and the effects of education and life experiences on our collective and interdependent relationships. We suggest that detailed, place-based studies such as ours contribute to the local understanding of sustainability management within SES contexts. At the same time, the findings from these place-based studies enrich the national and international discussions of how and why people perceive their relationships with their environments. We conclude that in order to make top-down generalizations about user/stakeholder groups in scalable frameworks, like ES, it is necessary to have bottom-up generated information to base it upon.

Author Contributions: Conceptualization, J.P.J.; methodology, J.P.J., G.S.D. and R.C.W.; software, J.P.J., G.S.D. and R.C.W.; validation, R.C.W.; formal analysis, J.P.J., G.S.D. and R.C.W.; investigation, J.P.J., G.S.D. and R.C.W.; resources, J.P.J., G.S.D.; data curation, R.C.W.; writing of the original draft preparation, J.P.J., G.S.D.; writing of review and editing, J.P.J. and R.C.W.; visualization, G.S.D. and R.C.W.; supervision, J.P.J.; project administration, J.P.J.; funding acquisition, J.P.J.

Funding: This research was funded by Texas State University through a Research Enhancement Program grant to J.P.J.

Acknowledgments: We are grateful to the San Marcos Convention \& Visitor Bureau and their Director Rebecca Ybarra-Ramirez for providing resources to assist in the commissioning of the student survey. We also thank the three anonymous reviewers who helped improve the content and clarity of this manuscript. The research reported in this paper contributes to the WaterSES project (pecswaterses.com), which is endorsed by the Programme on Ecosystem Change and Society (www.pecs-science.org).

Conflicts of Interest: The authors declare no conflicts of interest. The funder had no role in the design of the study; in the collection, analyses, or interpretation of data; in the writing of the manuscript; and in the decision to publish the results.

\section{Appendix A. Questionnaire Survey Instrument}

\section{(1). Do you live in San Marcos?}

1 -Yes

$2-\mathrm{No}$

\section{(2). How many years have you lived in San Marcos?}

\section{(3). Approximately how close (in miles) do you live to the San Marcos River?}

[You may enter a decimal place if appropriate.] 
(4). What is the zip code of where you currently live?

(5). What role did the San Marcos River play in your decision to attend Texas State University?

1-It was the primary reason I chose Texas State University.

2-It played a major role in my decision to attend Texas State University.

3-It played a minor role, being only one of many reasons I chose to attend Texas State University.

4-It did not factor into my decision to attend Texas State University.

(6). Have you visited the San Marcos River or its neighboring parks?

$1-$ Yes

2-No

(7). How many times do you visit the San Marcos River or its neighboring parks in a typical year?

(8). How many people usually accompany you on your visits to the San Marcos River and its neighboring parks?

1-None, I usually visit alone.

2-Usually one other person.

3-Usually two or three other people.

4-Usually in large groups of more than four people.

(9). During which seasons do you visit the San Marcos River?

[Mark all that apply.]

1 -Winter

2-Spring

3-Summer

4-Fall

(10). What times of day do you visit the San Marcos River?

[Mark all that apply.]

1-Morning

2-Afternoon

3-Night

(11). What activities do you participate in when visiting the San Marcos River and its neighboring parks? [List as many as you like, in order of preference with the first one being your most preferred.]

(12). How much money do you spend on your average visit to the river? Consider transportation and consumable goods separately. [Enter whole numbers only.]

Transportation: Gas, parking, public transit, etc.

Consumables: Food, drinks, ice, charcoal, sunscreen, etc.

(13). How much money do you spend on average per year for large, multiple use items such as (but not limited to) kayaks, canoes, tubes, fishing equipment, swim, fins, snorkels, and river shoes? [Enter whole numbers only.]

Annual total spent on multiple-use items.

(14). The San Marcos River provides benefits to fish and wildlife.

1-Strongly agree

2-Agree 
3-Neither Agree nor Disagree

4-Disagree

5-Strongly Disagree

(15). The San Marcos River provides benefits to human well-being.

1-Strongly agree

2-Agree

3-Neither Agree nor Disagree

4-Disagree

5-Strongly Disagree

(16). Rank the following benefits of the San Marcos River below.

[Click and drag choices, 1 being the most important at the top.]

1-6-A source of fish for your meals.

1-6-A source of water for municipal, industrial, or agricultural uses.

1-6-Clean and reliable water from the aquifer groundwater system.

1-6-A place for relaxing or enjoying the scenery and local culture.

1-6-A place for recreational fishing, swimming, tubing, and boating.

1-6-Habitat for plants and animals.

(17). Rank the following cultural benefits of the San Marcos River below.

[Click and drag choices, 1 being the most important at the top.]

1-6-Recreation: Tubing, fishing, boating, swimming, or physical health activities

1-6-Aesthetics: Relaxation, scenery, or sentimental value

1-6-Education: Opportunity to experience, learn about, or appreciate nature

1-6-Identity: Cultural heritage, local pride, sense of place, or symbol of San Marcos

1-6-Inspiration: Artistic, cultural, or work-related activities

1-6-Spirituality: Sacred, religious, or mental health activities

(18). In what order would you rank the importance of water in the San Marcos River?

[Click and drag choices, 1 being the most important at the top.]

1-3-Water is important for environmental health associated with water quantity, water quality, air quality, and habitat for plants and animals.

1-3-Water is important for non-material human uses associated with recreation, aesthetics, education, inspiration, spirituality, and identity.

1-3-Water is important for human consumption and use associated with municipal water supply, agriculture, and industry.

(19). In what order would you rank the importance of fish in the San Marcos River?

[Click and drag choices, 1 being the most important at the top.]

1-3-Fish are an important part of the ecosystem, being one part of the food web which also includes birds, mammals, insects, and plants.

1-3-Fish are important for human consumption, being high in protein, low in fat, and a source of fatty acids.

1-3-Fish are important for recreational fishing, aesthetics of viewing, and education of the environment.

(20). The environmental health of the San Marcos River is well managed and well protected.

1-Strongly Agree 
2-Agree

3-I am not aware of the environmental health of the San Marcos River

4-Disagree

5-Strongly Disagree

(21). If you were in charge of an annual fund dedicated to improvement of projects for the San Marcos River, how would you distribute the money? [The $100 \%$ is representative of all of the money in the fund. Total must add up to $100 \%$, whole numbers only.]

0-100 Add acreage to existing riverfront parks

0-100 Increase public outreach and environmental education

0-100 Protect or restore fish and wildlife habitat

0-100 Protect water quality

0-100 Collect landscaping, beautification, and trash

0-100 Protect aquifer and water quantity

0-100 Increase access and recreational opportunities for kayaks, canoes, tubes, and swimmers

0-100 Increase riverfront development for housing, dining, and shopping

(22). What dollar amount of your own money would you be willing to donate per year to a San Marcos River fund for the following improvements? You can donate to more than one fund, or none at all. [Whole numbers only]

$0-100,000^{*}$ Add acreage to existing riverfront parks

$0-100,000^{*}$ Increase public outreach and environmental education

$0-100,000 *$ Protect or restore fish and wildlife habitat

$0-100,000^{*}$ Protect water quality

$0-100,000^{*}$ Collect landscaping, beautification, and trash

$0-100,000^{*}$ Protect aquifer and water quantity

$0-100,000^{*}$ Increase access and recreational opportunities for kayaks, canoes, tubes, and swimmers

$0-100,000 *$ Increase riverfront development for housing, dining, and shopping

(23). Please describe how clean the San Marcos River is.

1 -Very Clean

2-Mostly Clean

3-I am not aware of the cleanliness of the San Marcos River

4-Slightly Dirty

5-Extremely Dirty

(24). Please list the reason(s) you chose to describe the river as dirty.

(25). Usually the water of the San Marcos River is clean and clear. If the river became dirty or cloudy, would you still enjoy it the way you do now?

$1-$ I would continue to enjoy the river the way I do now.

2-I would still enjoy the river, but less than I do now.

3-The cleanliness and clarity of the river has no effect on how much I enjoy the river.

4-If the river became dirty or cloudy, it would greatly reduce my ability to enjoy the river.

5 -I would avoid the river if it was a dirty or cloudy river.

6-I do not currently use or enjoy the river.

(26). What is your personal preference of the number of people in the river and parks when you visit?

1-No people

2-A few people 
3-Many people

4-Very many people

5-I do not visit the San Marcos River and neighboring parks.

(27). Click on the top five areas you visit on the San Marcos River, including areas not mentioned in the examples below.

[If you select more than five areas, your clicks will replace your original choices.]

(28). Do you appreciate having the San Marcos River in San Marcos?

$1-$ I greatly appreciate it.

2-I appreciate it somewhat.

3-I don't care one way or the other.

4-I don't appreciate it.

5-I wish it were not in San Marcos.

(29). Do you appreciate having Texas State University in San Marcos?

$1-$ I greatly appreciate it.

2-I appreciate it somewhat.

3-I don't care one way or the other.

4-I don't appreciate it.

5-I wish it were not in San Marcos.

(30). Do you appreciate having the Outlet Malls in San Marcos?

$1-$ I greatly appreciate it.

2-I appreciate it somewhat.

3-I don't care one way or the other.

4-I don't appreciate it.

5-I wish it were not in San Marcos.

(31). Rank the following in terms of the benefits they provide to San Marcos.

[Click and drag choices, 1 being the most beneficial at the top.]

1-3-Outlet Malls

1-3-San Marcos River

1-3-Texas State University

(32). Describe the amount of time you spent enjoying outdoor activities during childhood and adolescence.

1 -Regularly

2-Occasionally

3-Rarely

4-Never

(33). List the outdoor activities you enjoyed doing during childhood and adolescence with the first activity being your most enjoyed. [Enter "none" if your answer to the previous question was “Never".]

(34). Which setting best describes where you grew up?

1 -Rural

2-Suburban

3-Urban

(35). What is your student classification? 
1-Freshman

2-Sophomore

3-Junior

4-Senior/Postbaccalaureate

5-Masters/Professional

6-PhD

(36). What degree subject are you currently working towards?

(37). Have you been on one of the glass bottom boat tours at Spring Lake?

1 -Yes

$2-\mathrm{No}$

(38). Have you walked along the wetlands boardwalk at Spring Lake?

$1-$ Yes

$2-\mathrm{No}$

(39). Have you visited the educational displays and aquariums inside the Meadows Center building at Spring Lake?

1 -Yes

$2-\mathrm{No}$

(40). The San Marcos River contains endangered or threatened plant or animal species.

$1-$ Yes

2-No

3-I do not know

(41). How old are you?

$1-[<25]$

2-[25-34]

$3-[35-44]$

4- $[45-54]$

5-[55-64]

$6-[65+]$

(42). Gender

1-Male

2-Female

(43). Race or Origin

(You may select more than one)

1-American Indian or Alaskan Native

2-Asian

3-Black or African American

4-Hispanic or Latino or Spanish origin

5-Native Hawaiian or Other Pacific Islander

6-White or Anglo origin

7-Other

(44). Please indicate personal annual income

$1-[<\$ 20,000]$ 
$2-[\$ 20,000-\$ 40,000]$

$3-[>\$ 40,000-\$ 60,000]$

$4-[>\$ 60,000-\$ 80,000]$

$5-[>\$ 80,000]$

(45). What is(are) the occupation(s) of the person(s) who raised you?

(46). What is the highest level of education of the person(s) who raised you?

1-Some high school

2-High school graduate

3-Some college, but no degree

4-Associate or Technical degree

5-Bachelor's degree

6-Post-Graduate Masters or Professional degree

7-PhD, Law, or Medical degree

(47). The San Marcos River and its environment are sensitive to rapid urban growth.

1-Strongly Agree

2-Agree

3-Neither Agree nor Disagree

4-Disagree

5-Strongly Disagree

(48). Please explain your answer to the above question concerning the sensitivity of the San Marcos River to rapid urban growth.

(49). Is there anything else you would like to tell us regarding your use or perception of the San Marcos River? [If no, enter "no".]

\section{Appendix B.}

Table A1. Socio-demographic associations with use of San Marcos River cultural ecosystem services.

\begin{tabular}{|c|c|c|c|}
\hline $\begin{array}{l}\text { Independent } \\
\text { (Grouping) Variable: } \\
\text { Socio-Demographics }\end{array}$ & $\begin{array}{l}\text { Dependent Variable: San } \\
\text { Marcos River Use }\end{array}$ & $\begin{array}{c}\text { Test statistic: } \\
\text { K-W/Wilcoxon or } \emptyset^{2}, \\
\text { as Indicated }{ }^{\mathrm{c}}(\mathrm{df})\end{array}$ & $p$-Value \\
\hline \multirow{6}{*}{ Age } & Number of Annual Visits ${ }^{a}$ & $24.95(3)$ & $<0.001 * * *$ \\
\hline & Preferred Group Size ${ }^{b, c}$ & $132.28(3)$ & $<0.001^{* * *}$ \\
\hline & Visit in Winter $b, c$ & $9.44(3)$ & $0.024 *$ \\
\hline & Visit in Spring ${ }^{b, c}$ & $31.71(3)$ & $<0.001^{* * *}$ \\
\hline & Visit in Summer b,c & $1.09(3)$ & 0.780 \\
\hline & Visit in Fall ${ }^{b, c}$ & $2.87(3)$ & 0.413 \\
\hline \multirow{6}{*}{ Student Status } & Number of Annual Visits ${ }^{a}$ & $13.36(5)$ & $0.020 *$ \\
\hline & Preferred Group Size ${ }^{b, c}$ & $86.85(15)$ & $<0.001^{* * *}$ \\
\hline & Visit in Winter $\mathrm{b}, \mathrm{c}$ & $27.72(5)$ & $<0.001 * * *$ \\
\hline & Visit in Spring ${ }^{b, c}$ & $20.62(5)$ & $0.001 * *$ \\
\hline & Visit in Summer b,c & $28.17(5)$ & $<0.001 * * *$ \\
\hline & Visit in Fall ${ }^{b, c}$ & $5.96(5)$ & 0.310 \\
\hline \multirow{6}{*}{ Parents' Education } & Number of Annual Visits ${ }^{d}$ & $15.76(6)$ & $0.015^{*}$ \\
\hline & Preferred Group Size ${ }^{c, d}$ & $18.08(18)$ & 0.450 \\
\hline & Visit in Winter ${ }^{c, d}$ & $13.21(6)$ & $0.040^{*}$ \\
\hline & Visit in Spring ${ }^{c, d}$ & $22.20(6)$ & $0.001 * *$ \\
\hline & Visit in Summer $\mathrm{c}, \mathrm{d}$ & $19.15(6)$ & $0.004 * *$ \\
\hline & Visit in Fall ${ }^{c, d}$ & $12.45(6)$ & 0.053 \\
\hline
\end{tabular}

a 182 observations dropped due to missing information. ${ }^{\mathrm{b}} 141$ observations dropped due to missing information. ${ }^{c}$ Categorical-dependent variable; the chi-squared test for independence performed in place of the Kruskal-Wallis $(\mathrm{K}-\mathrm{W})$ test. ${ }^{\mathrm{d}} 185$ observations dropped due to missing information. ${ }^{*} p<0.05,{ }^{* *} p<0.01,{ }^{* * *} p<0.001$. 
Table A2. Life experience associations with use of San Marcos River cultural ecosystem services.

\begin{tabular}{|c|c|c|c|}
\hline $\begin{array}{l}\text { Independent (Grouping) } \\
\text { Variable: Life Experience }\end{array}$ & $\begin{array}{l}\text { Dependent Variable: San } \\
\text { Marcos River Use }\end{array}$ & $\begin{array}{c}\text { Test statistic: } \mathrm{K}-\mathrm{W} / \mathrm{Wilcoxon} \text { or } \emptyset^{2} \\
\text { as Indicated } \\
{ }^{\mathrm{c}}(\mathrm{df})\end{array}$ & $p$-Value \\
\hline \multirow{6}{*}{ San Marcos Resident } & Number of Annual Visits ${ }^{a}$ & $115.61(1)$ & $<0.001^{* * *}$ \\
\hline & Preferred Group Size b,c & $54.25(3)$ & $<0.001^{* * *}$ \\
\hline & Visit in Winter $b, c$ & $4.87(1)$ & $0.027^{*}$ \\
\hline & Visit in Spring b,c & $33.66(1)$ & $<0.001^{* * *}$ \\
\hline & Visit in Summer b,c & $10.03(1)$ & $<0.001^{* * *}$ \\
\hline & Visit in Fall ${ }^{b, c}$ & $27.83(1)$ & $<0.001^{* * *}$ \\
\hline \multirow{6}{*}{ Environment Raised } & Number of Annual Visits ${ }^{a}$ & $11.21(2)$ & $0.004^{* *}$ \\
\hline & Preferred Group Size b,c & $2.51(6)$ & 0.868 \\
\hline & Visit in Winter $b, c$ & $3.16(2)$ & 0.206 \\
\hline & Visit in Spring $b, c$ & $0.67(2)$ & 0.717 \\
\hline & Visit in Summer $b, c$ & $9.29(2)$ & $0.010 *$ \\
\hline & Visit in Fall b,c & $5.18(2)$ & 0.075 \\
\hline \multirow{6}{*}{ Time Outside as a Child ${ }^{\mathrm{d}}$} & Number of Annual Visits ${ }^{\text {a }}$ & $39.25(2)$ & $<0.001^{* * *}$ \\
\hline & Preferred Group Size b,c & $9.35(6)$ & 0.155 \\
\hline & Visit in Winter $b, c$ & $13.56(2)$ & $0.001^{* *}$ \\
\hline & Visit in Spring b,c & $4.60(2)$ & 0.100 \\
\hline & Visit in Summer b,c & $19.35(2)$ & $<0.001^{* * *}$ \\
\hline & Visit in Fall ${ }^{b, c}$ & $10.12(2)$ & $0.006^{* *}$ \\
\hline \multirow{6}{*}{ Glass Bottom Boat Tour } & Number of Annual Visits a & $20.75(1)$ & $<0.001^{* * *}$ \\
\hline & Preferred Group Size b,c & $5.51(3)$ & 0.138 \\
\hline & Visit in Winter $b, c$ & $12.94(1)$ & $<0.001^{* * *}$ \\
\hline & Visit in Spring b,c & $31.24(1)$ & $<0.001 * * *$ \\
\hline & Visit in Summer b,c & $<0.00(1)$ & 0.953 \\
\hline & Visit in Fall b,c & $6.59(1)$ & $0.010^{* *}$ \\
\hline
\end{tabular}

a 182 observations dropped due to missing information. ${ }^{b} 141$ observations dropped due to missing information. c Categorical-dependent variable; the chi-squared test for independence performed in place of the Kruskal-Wallis $(\mathrm{K}-\mathrm{W})$ test. ${ }^{\mathrm{d}}$ The categories "Rare" and "Never" were combined into the single category "Rare or Never" for these tests due to low observed frequencies. ${ }^{*} p<0.05,{ }^{* *} p<0.01,{ }^{* * *} p<0.001$.

Table A3. Life experience associations with perception/preference of San Marcos River.

\begin{tabular}{|c|c|c|c|}
\hline $\begin{array}{l}\text { Independent (Grouping) } \\
\text { Variable: Life Experience }\end{array}$ & $\begin{array}{l}\text { Dependent Variable: } \\
\text { Perception/Preferences }\end{array}$ & $\begin{array}{l}\text { K-W/Wilcoxon } \\
\text { Test Statistic (df) }\end{array}$ & $p$-Value \\
\hline \multirow{5}{*}{ San Marcos Resident } & Benefits Fish and Wildlife & $2.30(1)$ & 0.129 \\
\hline & Benefits Human Well-Being & $2.85(1)$ & 0.091 \\
\hline & Sensitive to Rapid Growth & $0.40(1)$ & 0.527 \\
\hline & Well-Managed and Protected & $26.64(1)$ & $<0.001^{* * *}$ \\
\hline & Clean & $35.24(1)$ & $<0.001^{* * *}$ \\
\hline \multirow{5}{*}{ Visited River in Last Year } & Benefits Fish and Wildlife & $50.98(1)$ & $<0.001 * * *$ \\
\hline & Benefits Human Well-Being & $84.88(1)$ & $<0.001^{* * *}$ \\
\hline & Sensitive to Rapid Growth & $65.78(1)$ & $<0.001^{* * *}$ \\
\hline & Well-Managed and Protected & $38.67(1)$ & $<0.001 * * *$ \\
\hline & Clean & $129.24(1)$ & $<0.001^{* * *}$ \\
\hline \multirow{5}{*}{ Environment Raised } & Benefits Fish and Wildlife & $3.49(2)$ & 0.175 \\
\hline & Benefits Human Well-Being & $4.67(2)$ & 0.097 \\
\hline & Sensitive to Rapid Growth & $1.25(2)$ & 0.534 \\
\hline & Well-Managed and Protected & $1.31(2)$ & 0.521 \\
\hline & Clean & $9.85(2)$ & $0.007^{* *}$ \\
\hline \multirow{5}{*}{ Time Outside as a Child ${ }^{\text {a }}$} & Benefits Fish and Wildlife & $16.67(2)$ & $<0.001^{* * *}$ \\
\hline & Benefits Human Well-Being & $27.25(2)$ & $<0.001 * * *$ \\
\hline & Sensitive to Rapid Growth & $20.73(2)$ & $<0.001^{* * *}$ \\
\hline & Well-Managed and Protected & $18.63(2)$ & $<0.001^{* * *}$ \\
\hline & Clean & $17.82(2)$ & $<0.001^{* * *}$ \\
\hline \multirow{5}{*}{ Glass Bottom Boat Tour } & Benefits Fish and Wildlife & $45.47(1)$ & $<0.001 * * *$ \\
\hline & Benefits Human Well-Being & $25.87(1)$ & $<0.001^{* * *}$ \\
\hline & Sensitive to Rapid Growth & $26.34(1)$ & $<0.001 * * *$ \\
\hline & Well-Managed and Protected & $33.96(1)$ & $<0.001^{* * *}$ \\
\hline & Clean & $64.04(1)$ & $<0.001^{* * *}$ \\
\hline
\end{tabular}

a The categories "Rare" and "Never" were combined into the single category "Rare or Never" for these tests due to low observed frequencies. ${ }^{*} p<0.05,{ }^{* *} p<0.01,{ }^{* * *} p<0.001$. 
Table A4. Life experience associations with ranking of San Marcos River ecosystem services.

\begin{tabular}{|c|c|c|c|}
\hline $\begin{array}{l}\text { Independent (Grouping) } \\
\text { Variable: Life Experience }\end{array}$ & $\begin{array}{c}\text { Dependent Variable: } \\
\text { Ecosystem Service Value }\end{array}$ & $\begin{array}{l}\text { K-W/Wilcoxon } \\
\text { Test Statistic (df) }\end{array}$ & $p$-Value \\
\hline \multirow{6}{*}{ San Marcos Resident } & Water Source & $2.02(1)$ & 0.155 \\
\hline & Food Source & $3.34(1)$ & 0.068 \\
\hline & Water Quality & $2.56(1)$ & 0.110 \\
\hline & Habitat & $5.88(1)$ & 0.015 * \\
\hline & Recreation & $15.89(1)$ & $<0.001^{* * *}$ \\
\hline & Sense of Place & $4.72(1)$ & 0.037 * \\
\hline \multirow{6}{*}{ Visited River in Last Year } & Water Source & $15.66(1)$ & $<0.001 * * *$ \\
\hline & Food Source & $4.71(1)$ & $0.030 *$ \\
\hline & Water Quality & $2.21(1)$ & 0.137 \\
\hline & Habitat & $3.92(1)$ & 0.048 * \\
\hline & Recreation & $25.29(1)$ & $<0.001^{* * *}$ \\
\hline & Sense of Place & $12.13(1)$ & $<0.001 * * *$ \\
\hline \multirow{6}{*}{ Environment Raised } & Water Source & $7.02(2)$ & $0.030 *$ \\
\hline & Food Source & $1.09(2)$ & 0.581 \\
\hline & Water Quality & $1.16(2)$ & 0.560 \\
\hline & Habitat & $0.25(2)$ & 0.882 \\
\hline & Recreation & $0.37(2)$ & 0.830 \\
\hline & Sense of Place & $1.69(2)$ & 0.431 \\
\hline \multirow{6}{*}{ Time Outside as a Child ${ }^{\text {a }}$} & Water Source & $0.73(2)$ & 0.694 \\
\hline & Food Source & $1.38(2)$ & 0.502 \\
\hline & Water Quality & $0.41(2)$ & 0.816 \\
\hline & Habitat & $15.62(2)$ & $<0.001 * * *$ \\
\hline & Recreation & $0.51(2)$ & 0.773 \\
\hline & Sense of Place & $4.72(2)$ & 0.094 \\
\hline \multirow{6}{*}{ Glass Bottom Boat Tour } & Water Source & $2.51(1)$ & 0.113 \\
\hline & Food Source & $1.56(1)$ & 0.211 \\
\hline & Water Quality & $3.52(1)$ & 0.061 \\
\hline & Habitat & $0.33(1)$ & 0.567 \\
\hline & Recreation & $0.02(1)$ & 0.875 \\
\hline & Sense of Place & $0.98(1)$ & 0.321 \\
\hline
\end{tabular}

a The categories "Rare" and "Never" were combined into the single category "Rare or Never" for these tests due to low observed frequencies; ${ }^{*} p<0.05,{ }^{* *} p<0.01,{ }^{* * *} p<0.001$.

Table A5. Life experience associations with ranking of San Marcos River cultural ecosystem services.

\begin{tabular}{cccc}
\hline $\begin{array}{c}\text { Independent (Grouping) } \\
\text { Variable: Life Experience }\end{array}$ & $\begin{array}{c}\text { Dependent Variable: Cultural } \\
\text { Ecosystem Service Value }\end{array}$ & $\begin{array}{c}\text { K-W/Wilcoxon } \\
\text { Test Statistic (df) }\end{array}$ & $p$-Value \\
\hline & Sense of Place & $2.29(1)$ & 0.130 \\
Recreation & $3.66(1)$ & 0.056 \\
San Marcos Resident & Spirituality & $1.40(1)$ & 0.236 \\
& Aesthetics & $0.831(1)$ & 0.362 \\
& Education & $10.64(1)$ & $0.001^{* *}$ \\
& Inspiration & $0.82(2)$ & 0.366 \\
\hline \multirow{2}{*}{ Visited River in Last Year } & Sense of Place & $1.22(1)$ & 0.269 \\
& Recreation & $17.51(1)$ & $<0.001^{* * *}$ \\
& Spirituality & $0.47(1)$ & 0.495 \\
& Aesthetics & $0.01(1)$ & 0.941 \\
& Education & $9.78(1)$ & $0.002^{* *}$ \\
& Inspiration & $3.41(1)$ & 0.065 \\
\hline Environment Raised & Sense of Place & $0.83(2)$ & 0.661 \\
& Recreation & $5.42(2)$ & 0.066 \\
& Spirituality & $2.29(2)$ & 0.318 \\
& Aesthetics & $0.40(2)$ & 0.819 \\
& Education & $1.24(2)$ & 0.538 \\
& Inspiration & $6.55(2)$ & $0.038^{*}$ \\
\hline & Sense of Place & $7.50(2)$ & $0.024 *$ \\
& Recreation & $1.59(2)$ & 0.452 \\
& Spirituality & $4.94(2)$ & 0.085 \\
& Aesthetics & $0.35(2)$ & 0.839 \\
& Education & $1.32(2)$ & 0.516 \\
& Inspiration & $6.39(2)$ & $0.041^{*}$ \\
\hline & Sense of Place & $5.46(1)$ & $0.020^{*}$ \\
& Recreation & $4.31(1)$ & $0.038^{*}$ \\
& Spirituality & $0.26(1)$ & 0.610 \\
& Aesthetics & $1.21(1)$ & 0.271 \\
& Education & $6.45(1)$ & $0.011^{*}$ \\
& Inspiration & $3.68(1)$ & 0.055 \\
\hline
\end{tabular}

a The categories "Rare" and "Never" were combined into the single category "Rare or Never" for these tests due to low observed frequencies. ${ }^{*} p<0.05,{ }^{* *} p<0.01,{ }^{* * *} p<0.001$. df: degrees of freedom. 
Table A6. Socio-demographic associations with ranking of San Marcos River ecosystem services.

\begin{tabular}{cccc}
\hline $\begin{array}{c}\text { Independent (Grouping) } \\
\text { Variable: Socio-Demographics }\end{array}$ & $\begin{array}{c}\text { Dependent Variable: } \\
\text { Ecosystem Service Value }\end{array}$ & $\begin{array}{c}\text { K-W/Wilcoxon } \\
\text { Test Statistic (df) }\end{array}$ & $p$-Value \\
\hline \multirow{2}{*}{ Age } & Water Source & $9.46(3)$ & $0.024^{*}$ \\
& Food Source & $1.75(3)$ & 0.625 \\
& Water Quality & $6.08(3)$ & 0.108 \\
& Habitat & $19.35(3)$ & $<0.001^{* * *}$ \\
& Recreation & $11.58(3)$ & $0.009^{* *}$ \\
& Sense of Place & $3.72(3)$ & 0.293 \\
\hline Student Status & Water Source & $6.48(5)$ & 0.262 \\
& Food Source & $5.29(5)$ & 0.381 \\
& Water Quality & $4.04(5)$ & 0.544 \\
& Habitat & $28.42(5)$ & $<0.001^{* * *}$ \\
& Recreation & $9.25(5)$ & 0.099 \\
& Sense of Place & $4.54(5)$ & 0.475 \\
\hline & Water Source & $6.74(6)$ & 0.345 \\
& Food Source & $13.65(6)$ & $0.034^{*}$ \\
& Water Quality & $2.20(6)$ & 0.901 \\
& Habitat & $15.69(6)$ & $0.016^{*}$ \\
& Recreation & $5.96(6)$ & 0.428 \\
& Sense of Place & $4.39(6)$ & 0.624 \\
\hline
\end{tabular}

${ }^{a} 4$ observations dropped due to missing information. ${ }^{*} p<0.05,{ }^{* *} p<0.01,{ }^{* * *} p<0.001$.

Table A7. Socio-demographic associations with ranking of San Marcos River cultural ecosystem services.

\begin{tabular}{cccc}
\hline $\begin{array}{c}\text { Independent (Grouping) } \\
\text { Variable: Socio-Demographics }\end{array}$ & $\begin{array}{c}\text { Dependent Variable: Cultural } \\
\text { Ecosystem Service Value }\end{array}$ & $\begin{array}{c}\text { K-W/Wilcoxon } \\
\text { Test Statistic (df) }\end{array}$ & $p$-Value \\
\hline \multirow{2}{*}{ Age } & Sense of Place & $2.59(3)$ & 0.459 \\
& Recreation & $34.59(3)$ & $<0.001^{* * *}$ \\
& Spirituality & $16.87(3)$ & $<0.001^{* * *}$ \\
& Aesthetics & $4.06(3)$ & 0.255 \\
& Education & $17.65(3)$ & $<0.001^{* * *}$ \\
& Inspiration & $3.17(3)$ & 0.366 \\
\hline Student Status & Sense of Place & $9.46(5)$ & 0.092 \\
& Recreation & $25.49(5)$ & $<0.001^{* * *}$ \\
& Spirituality & $8.16(5)$ & 0.148 \\
& Aesthetics & $7.59(5)$ & 0.180 \\
& Education & $18.83(5)$ & $0.002^{* *}$ \\
& Inspiration & $16.86(5)$ & 0.005 \\
\hline
\end{tabular}

a 4 observations dropped due to missing information. ${ }^{*} p<0.05,{ }^{* *} p<0.01,{ }^{* * *} p<0.001$. 
Table A8. Socio-demographic associations with perception/preference of San Marcos River.

\begin{tabular}{cccc}
\hline $\begin{array}{c}\text { Independent (Grouping) } \\
\text { Variable: Socio-Demographics }\end{array}$ & $\begin{array}{c}\text { Dependent Variable: } \\
\text { Perception/Preferences }\end{array}$ & $\begin{array}{c}\text { K-W/Wilcoxon } \\
\text { Test Statistic (df) }\end{array}$ & $\boldsymbol{p}$-Value \\
\hline \multirow{2}{*}{ Age } & Benefits Fish and Wildlife & $3.69(3)$ & 0.297 \\
& Benefits Human Well-Being & $7.87(3)$ & $0.049^{*}$ \\
& Sensitive to Rapid Growth & $22.1(3)$ & $<0.001^{* * *}$ \\
& Well-Managed and Protected & $23.48(3)$ & $<0.001^{* * *}$ \\
& Clean & $27.71(3)$ & $<0.001^{* * *}$ \\
\hline \multirow{2}{*}{ Student Status } & Benefits Fish and Wildlife & $13.01(5)$ & $0.023^{*}$ \\
& Benefits Human Well-Being & $18.10(5)$ & $0.003^{* *}$ \\
& Sensitive to Rapid Growth & $29.50(5)$ & $<0.001^{* * *}$ \\
& Well-Managed and Protected & $41.38(5)$ & $<0.001^{* * *}$ \\
& Clean & $37.60(5)$ & $<0.001^{* * *}$ \\
\hline & Benefits Fish and Wildlife & $7.17(6)$ & 0.306 \\
Parents' Education ${ }^{*}{ }^{*}$ & Benefits Human Well-Being & $12.76(6)$ & $0.047^{*}$ \\
& Sensitive to Rapid Growth & $19.55(6)$ & $0.003^{* *}$ \\
& Well-Managed and Protected & $8.50(6)$ & 0.204 \\
& Clean & $7.13(6)$ & 0.309 \\
\hline
\end{tabular}

${ }^{\mathrm{a}} 4$ observations dropped due to missing information. ${ }^{*} p<0.05,{ }^{* *} p<0.01,{ }^{* * *} p<0.001$.

\section{References}

1. Foley, R.; Kistemann, T. Blue space geographies: Enabling health in place. Health Place 2015, 35, 157-165. [CrossRef] [PubMed]

2. Völker, S.; Kistemann, T. The impact of blue space on human health and well-being-Salutogenetic health effects of inland surface waters: A review. Int. J. Hyg. Environ. Health 2011, 214, 449-460. [CrossRef] [PubMed]

3. Nichols, W.J. Blue Mind: The Surprising Science That Shows How Being Near, In, On, or under Water Can Make You Happier, Healthier, More Connected, and Better at What You Do; Little, Brown and Company: New York, NY, USA, 2014; p. 333.

4. Brauman, K.A.; Daily, G.C.; Duarte, T.K.; Mooney, H.A. The nature and value of ecosystem services: An overview highlighting hydrologic services. In Annual Review of Environment and Resources; Annual Reviews: Palo Alto, CA, USA, 2007; Volume 32, pp. 67-98.

5. Ostrom, E. A General Framework for Analyzing Sustainability of Social-Ecological Systems. Science 2009, 325, 419-422. [CrossRef] [PubMed]

6. Sivapalan, M.; Savenije Hubert, H.G.; Blöschl, G. Socio-hydrology: A new science of people and water. Hydrol. Process. 2012, 26, 1270-1276. [CrossRef]

7. Millenium Ecosystem Assessment. Ecosystems and Human Well-Being: Synthesis; Island Press: Washington, DC, USA, 2005; p. 155.

8. Haines-Young, R.; Potschin, M. Common International Classification of Ecosystem Services (CICES): Consultation on Version 4; European Environment Agency: Nottingham, UK, 2013; p. 34.

9. Kankaala, P.; Nõges, T.; Rask, M.; Straile, D.; Terzhevik, A. Preface: European large lakes-ecosystem services and management in a changing world. Hydrobiologia 2016, 780, 1-3. [CrossRef]

10. Darvill, R.; Lindo, Z. The inclusion of stakeholders and cultural ecosystem services in land management trade-off decisions using an ecosystem services approach. Landsc. Ecol. 2016, 31, 533-545. [CrossRef]

11. Fulford, R.; Yoskowitz, D.; Russell, M.; Dantin, D.; Rogers, J. Habitat and recreational fishing opportunity in Tampa Bay: Linking ecological and ecosystem services to human beneficiaries. Ecosyst. Serv. 2016, 17, 64-74. [CrossRef]

12. MacDiarmid, A.B.; Law, C.S.; Pinkerton, M.; Zeldis, J. New Zealand marine ecosystem services. In Ecosystem Services in New Zealand-Conditions and Trends; Dymond, J.R., Ed.; Manaaki Whenua Press: Lincoln, New Zealand, 2013; pp. 238-253. 
13. Martin-Ortega, J.; Ferrier, R.C.; Gordon, I.J.; Khan, S. Water Ecosystem Services: A Global Perspective; Cambridge University Press: Cambridge, UK, 2015; p. 194.

14. Crossman, N.D.; Burkhard, B.; Nedkov, S.; Willemen, L.; Petz, K.; Palomo, I.; Drakou, E.G.; Martín-Lopez, B.; McPhearson, T.; Boyanova, K.; et al. A blueprint for mapping and modelling ecosystem services. Ecosyst. Serv. 2013, 4, 4-14. [CrossRef]

15. Burkhard, B.; Kroll, F.; Nedkov, S.; Müller, F. Mapping ecosystem service supply, demand and budgets. Ecol. Indic. 2012, 21, 17-29. [CrossRef]

16. Cebrián-Piqueras, M.A.; Karrasch, L.; Kleyer, M. Coupling stakeholder assessments of ecosystem services with biophysical ecosystem properties reveals importance of social contexts. Ecosyst. Serv. 2017, 23, 108-115. [CrossRef]

17. Wei, H.; Fan, W.; Wang, X.; Lu, N.; Dong, X.; Zhao, Y.; Ya, X.; Zhao, Y. Integrating supply and social demand in ecosystem services assessment: A review. Ecosyst. Serv. 2017, 25, 15-27. [CrossRef]

18. Martín-López, B.; Iniesta-Arandia, I.; García-Llorente, M.; Palomo, I.; Casado-Arzuaga, I.; Amo, D.G.D.; Gómez-Baggethun, E.; Oteros-Rozas, E.; Palacios-Agundez, I.; Willaarts, B.; et al. Uncovering Ecosystem Service Bundles through Social Preferences. PLoS ONE 2012, 7, e38970. [CrossRef] [PubMed]

19. Hein, L.; van Koppen, K.; de Groot, R.S.; van Ierland, E.C. Spatial scales, stakeholders and the valuation of ecosystem services. Ecol. Econ. 2006, 57, 209-228. [CrossRef]

20. Martinez-Harms, M.J.; Bryan, B.A.; Balvanera, P.; Law, E.A.; Rhodes, J.R.; Possingham, H.P.; Wilson, K.A. Making decisions for managing ecosystem services. Biol. Conserv. 2015, 184, 229-238. [CrossRef]

21. de Groot, R.S.; Wilson, M.A.; Boumans, R.M.J. A typology for the classification, description and valuation of ecosystem functions, goods and services. Ecol. Econ. 2002, 41, 393-408. [CrossRef]

22. Kenter, J.O.; O’Brien, L.; Hockley, N.; Ravenscroft, N.; Fazey, I.; Irvine, K.N.; Reed, M.S.; Christie, M.; Brady, E.; Bryce, R.; et al. What are shared and social values of ecosystems? Ecol. Econ. 2015, 111, 86-99. [CrossRef]

23. Castro, A.J.; Vaughn, C.C.; Julian, J.P.; García-Llorente, M. Social Demand for Ecosystem Services and Implications for Watershed Management. J. Am. Water Resour. Assoc. 2016, 52, 209-221. [CrossRef]

24. Hauck, J.; Saarikoski, H.; Turkelboom, F.; Keune, H. Stakeholder Analysis in ecosystem service decision-making and research. In OpenNESS Ecosystem Services Reference Book; Potschin, M., Jax, K., Eds.; European Centre for Nature Conservation: Tilburg, The Netherlands, 2016.

25. Arnett, J.J. Emerging adulthood: A theory of development from the late teens through the twenties. Am. Psychol. 2000, 55, 469-480. [CrossRef] [PubMed]

26. Arnett, J.J. Emerging Adulthood: What Is It, and What Is It Good For? Child Dev. Perspect. 2007, 1, 68-73. [CrossRef]

27. Blanco, C.; Okuda, M.; Wright, C.; Hasin, D.S.; Grant, B.F.; Liu, S.M.; Olfson, M. Mental health of college students and their non-college-attending peers: Results from the national epidemiologic study on alcohol and related conditions. Arch. Gen. Psychiatry 2008, 65, 1429-1437. [CrossRef] [PubMed]

28. Coccia, C.; Darling, C.A. Having the Time of Their Life: College Student Stress, Dating and Satisfaction with Life. Stress Health 2016, 32, 28-35. [CrossRef] [PubMed]

29. Chawla, L. Significant Life Experiences Revisited: A Review of Research on Sources of Environmental Sensitivity. J. Environ. Educ. 1998, 29, 11-21. [CrossRef]

30. Priego, C.; Breuste, J.-H.; Rojas, J. Perception and Value of Nature in Urban Landscapes: A Comparative Analysis of Cities in Germany, Chile and Spain. Landsc. Online 2008, 7, 22. [CrossRef]

31. McFarland, A.L.; Waliczek, T.M.; Zajicek, J.M. The Relationship between Student Use of Campus Green Spaces and Perceptions of Quality of Life. HortTechnology 2008, 18, 232-238.

32. Speake, J.; Edmondson, S.; Nawaz, H. Everyday encounters with nature: Students' perceptions and use of university campus green spaces. Hum. Geogr. 2013, 7, 21-31. [CrossRef]

33. Hipp, J.A.; Gulwadi, G.B.; Alves, S.; Sequeira, S. The Relationship between Perceived Greenness and Perceived Restorativeness of University Campuses and Student-Reported Quality of Life. Environ. Behav. 2016, 48, 1292-1308. [CrossRef]

34. Windhorst, E.; Williams, A. "It's like a different world": Natural places, post-secondary students, and mental health. Health Place 2015, 34, 241-250. [CrossRef] [PubMed]

35. Kimmel, J. The San Marcos: A River's Story; Texas A\&M University Press: College Station, TX, USA, 2006. 
36. United States Fish and Wildlife Sservice. Draft Environmental Impact Statement: Edwards Aquifer Recovery Implementation Program, Habitat Conservation Program; U.S. Fish and Wildlife Service: Austin, TX, USA, 2012; p. 1728.

37. Greater San Marcos Partnership. Major Employers; Greater San Marcos Partnership: San Marcos, CA, USA, 2017; Available online: https:/ / greatersanmarcostx.com/major-employers (accessed on 19 May 2017).

38. City of San Marcos. City of San Marcos Parks, Recreation E Open Space Master Plan; City of San Marcos: San Marcos, CA, USA, 2010; p. 117.

39. Greater San Marcos Partnership. Rankings; Greater San Marcos Partnership: San Marcos, CA, USA, 2017; Available online: https:/ / greatersanmarcostx.com/rankings (accessed on 19 May 2017).

40. Bertram, C.; Rehdanz, K. Preferences for cultural urban ecosystem services: Comparing attitudes, perception, and use. Ecosyst. Serv. 2015, 12, 187-199. [CrossRef]

41. García-Llorente, M.; Iniesta-Arandia, I.; Willaarts, B.A.; Harrison, P.A.; Berry, P.; Bayo, M.M.; Castro, A.J.; Montes, C.; Martín-López, B. Biophysical and sociocultural factors underlying spatial trade-offs of ecosystem services in semiarid watersheds. Ecol. Soc. 2015, 20, 39. [CrossRef]

42. Porter, S.R.; Whitcomb, M.E. Non-Response in Student Surveys: The Role of Demographics, Engagement and Personality. Res. Higher Educ. 2005, 46, 127-152. [CrossRef]

43. Porter, S.R.; Umbach, P.D. Student Survey Response Rates across Institutions: Why Do they Vary? Res. Higher Educ. 2006, 47, 229-247. [CrossRef]

44. Gumprecht, B. The American college town. Geogr. Rev. 2003, 93, 51-80. [CrossRef]

45. Nisbet, E.K.; Zelenski, J.M.; Murphy, S.A. The Nature Relatedness Scale: Linking Individuals' Connection With Nature to Environmental Concern and Behavior. Environ. Behav. 2009, 41, 715-740. [CrossRef]

46. Seitz, C.M.; Reese, R.F.; Strack, R.W.; Frantz, S.; West, B. Identifying and improving green spaces on a college campus: A photovoice study. Ecopsychology 2014, 6, 98-108. [CrossRef]

47. Castro, A.J.; Martín-López, B.; García-Llorente, M.; Aguilera, P.A.; López, E.; Cabello, J. Social preferences regarding the delivery of ecosystem services in a semiarid Mediterranean region. J. Arid Environ. 2011, 75, 1201-1208. [CrossRef]

48. Larson, L.R.; Keith, S.J.; Fernandez, M.; Hallo, J.C.; Shafer, C.S.; Jennings, V. Ecosystem services and urban greenways: What's the public's perspective? Ecosyst. Serv. 2016, 22, 111-116. [CrossRef]

49. Fleuret, S.; Prugneau, J. Assessing students' wellbeing in a spatial dimension. Geogr. J. 2015, 181, 110-120. [CrossRef]

50. Gómez-Baggethun, E.; Barton, D.; Berry, P.; Dunford, R.; Harrison, P.A. Concepts and methods in ES valuation. In Routledge Handbook of Ecosystem Services; Potschin, M., Haines-Young, R., Fish, R., Turner, R.K., Eds.; Taylor \& Francis: London, UK, 2016; pp. 99-111.

51. Fish, R.; Church, A.; Winter, M. Conceptualising cultural ecosystem services: A novel framework for research and critical engagement. Ecosyst. Serv. 2016, 21, 208-217. [CrossRef]

52. Chan, K.M.A.; Satterfield, T. Managing cultural ecosystem services for sustainability. In Routledge Handbook of Ecosystem Services; Potschin, M., Haines-Young, R., Fish, R., Turner, R.K., Eds.; Taylor \& Francis: London, UK, 2016; pp. 343-351.

53. Chan, K.M.A.; Satterfield, T.; Goldstein, J. Rethinking ecosystem services to better address and navigate cultural values. Ecol. Econ. 2012, 74, 8-18. [CrossRef]

54. Hirons, M.; Comberti, C.; Dunford, R. Valuing Cultural Ecosystem Services. Ann. Rev. Environ. Resour. 2016, 41, 545-574. [CrossRef]

55. Glaser, M.; Krause, G.; Ratter, B.; Welp, M. Human-Nature Interactions in the Anthropocene; Potentials of Social-Ecological Systems Analysis; Routledge: New York, NY, USA, 2012.

56. Becker, E. Social-Ecological Systems as Epistemic Objects. In Human-Nature Interactions in the Anthropocene: Potentials of Social-Ecological Systems Analysis; Glaser, M., Krause, G., Ratter, B., Welp, M., Eds.; Routledge: New York, NY, USA, 2012; pp. 37-59.

57. Baur, J.W.R.; Tynon, J.F.; Gómez, E. Attitudes about urban nature parks: A case study of users and nonusers in Portland, Oregon. Landsc. Urban Plan. 2013, 117, 100-111. [CrossRef]

58. Lewicka, M. Place attachment: How far have we come in the last 40 years? J. Environ. Psychol. 2011, 31, 207-230. [CrossRef]

59. Williams, C.C.; Chawla, L. Environmental identity formation in nonformal environmental education programs. Environ. Educ. Res. 2016, 22, 978-1001. [CrossRef] 
60. Krasny, M.E.; Roth, W.M. Environmental education for social-ecological system resilience: A perspective from activity theory. Environ. Educ. Res. 2010, 16, 545-558. [CrossRef]

61. Rioux, L.; Scrima, F.; Werner, C.M. Space appropriation and place attachment: University students create places. J. Environ. Psychol. 2017, 50, 60-68. [CrossRef]

62. Sebba, R. The Landscapes of Childhood: The Reflection of Childhood's Environment in Adult Memories and in Children's Attitudes. Environ. Behav. 1991, 23, 395-422. [CrossRef]

63. Thompson, C.W.; Aspinall, P.; Montarzino, A. The Childhood Factor: Adult Visits to Green Places and the Significance of Childhood Experience. Environ. Behav. 2008, 40, 111-143. [CrossRef]

64. Hester, R.T. Design for Ecological Democracy; MIT press: Cambridge, UK, 2006; 524p.

65. Cortese, A.D. The critical role of higher education in creating a sustainable future. Plan. Higher Educ. 2003, 3, $15-22$.

(C) 2018 by the authors. Licensee MDPI, Basel, Switzerland. This article is an open access article distributed under the terms and conditions of the Creative Commons Attribution (CC BY) license (http://creativecommons.org/licenses/by/4.0/). 